\section{Mulch and Fertilizer Management Practices for Organic Production of Highbush Blueberry. II. Impact on Plant and Soil Nutrients during Establishment}

\author{
Handell Larco ${ }^{1}$ and Bernadine C. Strik ${ }^{2,3}$ \\ Department of Horticulture, Oregon State University, 4017 ALS, Corvallis, \\ OR 97331 \\ David R. Bryla \\ U.S. Department of Agriculture, Agricultural Research Service, Horticultural \\ Crops Research Unit, 3420 NW Orchard Avenue, Corvallis, OR 97330
}

\section{Dan M. Sullivan \\ Department of Crop and Soil Science, Oregon State University, 3045 ALS, Corvallis, OR 97331}

Additional index words. compost, feather meal, fish emulsion, landscape fabric, macronutrients, micronutrients, nitrogen, raised beds, sawdust, tissue nutrient concentration, Vaccinium corymbosum, weed mat

Abstract. A systems trial was established in Oct. 2006 to evaluate management practices for organic production of northern highbush blueberry (Vaccinium corymbosum $\mathbf{L}$.). The practices included: flat and raised planting beds; feather meal and fish emulsion fertilizer each applied at rates of 29 and $57 \mathrm{~kg} \cdot \mathrm{ha}^{-1}$ nitrogen $(\mathrm{N})$; sawdust mulch, compost topped with sawdust mulch (compost + sawdust), or weed mat; and two cultivars, Duke and Liberty. Each treatment was irrigated by drip and weeds were controlled as needed. The planting was certified organic in 2008 . Bed type affected most leaf nutrients measured in one or both cultivars during the first year after planting, including $\mathrm{N}$, phosphorus $(\mathrm{P})$, potassium $(\mathrm{K})$, calcium $(\mathrm{Ca})$, magnesium $(\mathrm{Mg})$, boron $(\mathrm{B})$, manganese (Mn), and zinc ( $\mathrm{Zn})$, but had less of an effect on leaf nutrients and no effect on soil $\mathrm{pH}$, organic matter, or soil nutrients measured the next year. Feather meal contained 12 times more $\mathrm{Ca}$ and seven times more $\mathrm{B}$ than fish emulsion and resulted in higher levels of soil $\mathrm{Ca}$ and soil and leaf $\mathrm{B}$ in both cultivars, whereas fish emulsion contained three times more $P, 100$ times more $K$, and 60 times more copper $(\mathrm{Cu})$ and resulted in higher levels of soil $P, K$, and $C u$ as well as a higher level of leaf $P$ and $K$. Fish emulsion also reduced soil $\mathrm{pH}$. Compost + sawdust mulch increased soil $\mathrm{pH}$ and organic matter and resulted in higher levels of soil nitrate- $\mathrm{N}\left(\mathrm{NO}_{3}-\mathrm{N}\right), \mathrm{P}, \mathrm{K}, \mathrm{Ca}, \mathrm{B}, \mathrm{Cu}$, and $\mathrm{Zn}$ than sawdust alone and increased leaf $K$ and $B$. Weed mat, in contrast, resulted in the lowest soil $\mathrm{pH}$ and increased soil ammonium- $\mathrm{N}\left(\mathrm{NH}_{4}-\mathrm{N}\right)$. Weed mat also reduced soil Ca and $\mathrm{Mg}$, but its effects on leaf nutrients were variable. Leaf $\mathrm{Ca}, \mathrm{Mg}$, and $\mathrm{B}$ were below levels recommended for blueberry the first year after planting when plants were fertilized with fish emulsion, whereas leaf $N$ was low or deficient on average in the second year when plants were fertilized with feather meal. Leaf $B$ was also low the second year in all treatments, and leaf $\mathrm{Cu}$ was marginally low. Leaf $\mathrm{K}$, conversely, increased from the previous year and was becoming marginally high with fish emulsion. Fish emulsion, weed mat, and compost were generally the most favorable practices in terms of plant and soil nutrition. However, given the impact of each on soil $\mathrm{pH}$ and/or plant and soil $\mathrm{K}$, further investigation is needed to determine whether these practices are sustainable over the long term for both conventional and organic production of highbush blueberry.

Certified organic blueberry (Vaccinium sp.) production has increased rapidly in the United States from an estimated 194 ha in 2003 to 1665 ha $(40 \%$ of the total worldwide) in 2011 (Strik, unpublished data). The main challenges to such rapid expansion include greater production costs or input, limited options for disease or pest control, and reduced yields in organic plantings (Julian et al., 2011a).
Organic crops usually command higher prices than those produced conventionally, but higher may not always outweigh added associated with more expensive agricultura inputs.

Most new blueberry fields, including those used for organic production, are planted on raised beds (Strik, 2007). Raised beds improve soil drainage and help protect sus- ceptible cultivars from developing problems with phytophthora root rot (Bryla et al., 2008; Scherm and Krewer, 2008). Two cultivars of northern highbush blueberry, 'Duke' and 'Liberty', had more growth and fruit production on raised beds than on flat ground in an organic field in Oregon (Larco et al., 2013). Both of these cultivars are popular choices commercially and are commonly used for organic production in the northwestern United States (Julian et al., 2011a).

Like many crops, fertilizer practices in blueberry are routinely adjusted based on leaf tissue analysis. Nitrogen is the predominant nutrient applied to blueberry, and the best growth and yield is usually achieved with $\approx 25$ to $100 \mathrm{~kg} \cdot \mathrm{ha}^{-1} \mathrm{~N}$ in conventional systems (Bañados et al., 2012; Chandler and Mason, 1942; Eck, 1988; Griggs and Rollins, 1947; Hanson, 2006; Hart et al., 2006). The most common $\mathrm{N}$ fertilizers applied to blueberry are ammonium sulfate and urea in conventional systems and Organic Materials Review Institute-approved fish emulsion or feather meal in organic systems. Most species of blueberry are adapted to low soil $\mathrm{pH}$ conditions in the range of 4.5 to 5.5 and require $\mathrm{NH}_{4}-\mathrm{N}$ over $\mathrm{NO}_{3}-\mathrm{N}$ for uptake. Nitrogen uptake increases throughout the growing season in young plants but primarily occurs during shoot and early fruit development in the spring in mature plants (Bañados et al., 2012; Retamales and Hanson, 1989; Throop and Hanson, 1997). The current recommendation is to apply $\mathrm{N}$ in split applications in the spring when using granular fertilizers (April to June in the northern hemisphere; Hart et al., 2006) or to inject it gradually through the irrigation system ("fertigation") from spring to midsummer when using drip and liquid fertilizers (Bryla and Machado, 2011). Many organic blueberry farmers commonly apply liquid fish emulsion to the soil directly, however, especially in young plantings. Granular feather meal products are also applied directly to the in-row area. Many nutrients other than $\mathrm{N}$ are present in organic fertilizers and are thus applied to the planting whether required or not. The impact of using organic fertilizers on plant and soil nutrient levels is largely unknown in most crops, including blueberry.

Compost is also used by many organic blueberry growers to increase soil organic matter content and provide additional nutrients. Depending on the feedstock, compost supplies $3 \%$ to $10 \%$ of the total $\mathrm{N}$ during decomposition for several years after application (Gale et al., 2006; Sikora and Szmidt, 2001). Burkhard et al. (2009) found greater growth and yield in blueberry when using seafood- or manure-based composts. Larco et al. (2013) also reported better growth and yield in blueberry when using yard-debris compost covered with sawdust mulch than when using sawdust mulch alone.

Sawdust mulch is often used for weed control as well as other benefits in blueberry such as reducing soil water loss and increasing soil organic matter content (Burkhard et al., 2009; Clark and Moore, 1991; Karp 
et al., 2006; Kozinski, 2006; Krewer et al., 2009; Savage, 1942; Sciarappa et al., 2008; White, 2006). Sawdust is becoming expensive in many growing regions (Julian et al., 2011a, 2011b). It also has a very high carbon (C)-to-N ratio, and therefore, as it decomposes, it tends to immobilize $\mathrm{N}$ applied from fertilizers (White, 2006). Hart et al. (2006) recommend applying an additional $25 \mathrm{~kg} \cdot \mathrm{ha}^{-1}$ $\mathrm{N}$ for an 8-cm deep layer of fresh sawdust applied. Although the extra fertilizer is a relatively minor expense in conventional systems, it is costly and often more difficult to apply when using organic products.

Many organic growers are using weed mat as an alternative to sawdust. Weed mat is a woven, polyethylene landscape fabric or groundcover, which is usually black in color and permeable to water. Weed mat reduces weed management costs and results in a higher early yield than sawdust in blueberry (Julian et al., 2012; Krewer et al., 2009; Larco et al., 2013; Sciarappa et al., 2008). The material also likely affects availability and uptake of nutrients differently than sawdust and other organic mulches as a result of its numerous impacts on soil properties. For example, soil temperature is typically higher during the day with (black) weed mat, water infiltration is often lower, and blueberry root growth is reduced (Cox, 2009; Larco, 2010; Larco et al., 2013; Neilsen et al., 2003). Most new fields are irrigated by drip when using weed mat.

The objectives of the present study were to evaluate the effects of bed type, organic fertilizers, and different mulches on availability of soil nutrients and plant nutrient status in a new organic planting of highbush blueberry. The study included 'Duke' and 'Liberty' blueberry and was conducted during the first 2 years after establishment.

\section{Materials and Methods}

Study site. A 0.43-ha research trial was established 9 Oct. 2006 on a site in transition to organic production at the North Willamette Research and Extension Center (NWREC; lat. $45^{\circ} 16^{\prime} 47.55^{\prime \prime} \mathrm{N}$, long. $122^{\circ} 45^{\prime} 21.90^{\prime \prime}$ $\mathrm{W})$ in Aurora, OR. Soil at the site is a Willamette silt loam (fine-silty mixed superactive

Received for publication 22 Aug. 2013. Accepted for publication 11 Oct. 2013.

We recognize the financial support provided by the Oregon Blueberry Commission, the Northwest Center for Small Fruits Research, the Washington Blueberry Commission, the USDA National Institute of Food and Agriculture (Formula Grant No. OREI 2008-513000-04443), and our industry contributors. We appreciate the valuable assistance of Emily Vollmer and Gil Buller at the NWREC, Oregon State University.

${ }^{1}$ Former M.S. Graduate Student, Department of Horticulture, Oregon State University. Present address: Driscoll Strawberry Associates, Inc., 1750 San Juan Road, Aromas, CA 95004.

${ }^{2}$ Professor and Extension Berry Crops Specialist.

${ }^{3}$ To whom reprint requests should be addressed; e-mail strikb@hort.oregonstate.edu. mesic Pachic Ultic Argixeroll). The planting was certified as organic in May 2008 by Oregon Tilth (OTCO, Salem, OR). Detailed information on site preparation and planting is provided in Larco et al. (2013).

Experimental design. Treatments were arranged in a split-split plot design and included two bed types (one row as a raised bed and one row on flatground, referred to as a flat bed) as main plots, two types and rates of fertilizer [feather meal (Nature Safe, Cold Spring, KY) and fish emulsion (Fish Agra; Northeast Organics Inc., Manchester-by-theSea, MA) each applied at a rate of 29 and 57 $\mathrm{kg} \cdot \mathrm{ha}^{-1} \mathrm{~N}$ ] as subplots, and a combination of three mulch types [douglas fir (Pseudotsuga menziesii M.) sawdust ( $9 \mathrm{~cm}$ deep; $\left.360 \mathrm{~m}^{3} \cdot \mathrm{ha}^{-1}\right)$, yard debris compost ( $4 \mathrm{~cm}$ deep; $152 \mathrm{~m}^{3} \cdot \mathrm{ha}^{-1}$ ) covered with $5 \mathrm{~cm}$ of douglas fir sawdust $\left(200 \mathrm{~m}^{3} \cdot \mathrm{ha}^{-1}\right)$ for weed control ("compost + sawdust"), and weed mat (landscape fabric) with $5 \mathrm{~cm}$ of sawdust mulch applied over the planting hole $\left(20 \mathrm{~cm}\right.$ diameter; $\left.7 \mathrm{~m}^{3} \cdot \mathrm{ha}^{-1}\right)$ cut in the weed mat] and two cultivars (Duke and Liberty) as sub-subplots with five replicates per treatment and seven plants per treatment plot. Plants were spaced $0.75 \mathrm{~m}$ apart within plots and $1.5 \mathrm{~m}$ apart between plots. The planting had a total of 12 rows spaced $3.0 \mathrm{~m}$ apart and included a border row on each side (4385 plants/ha).

Mulch materials. Sawdust (Decorative Bark, Lyons, OR) and compost (Rexius, Eugene, OR) mulches were applied on 12 Oct. 2006, and weed mat (water flow rate 6.8 $\mathrm{L} \cdot \mathrm{h}^{-1} \cdot \mathrm{m}^{-2} ; 0.11 \mathrm{~kg} \cdot \mathrm{m}^{-2}$; TenCate Protective Fabrics, OBC Northwest, Inc., Canby, OR) was installed on top of the beds on $1 \mathrm{Feb}$. 2007. The sawdust was aged $2+$ years before application, which is typical for commercial blueberry production. Yard debris compost was prepared from a mixture of woody tree and shrub trimmings collected from urban yard maintenance. Composting took place outdoors in windrows with $\approx 30 \mathrm{~d}$ of active (greater than $50^{\circ} \mathrm{C}$ ) composting followed by 90 to $180 \mathrm{~d}$ of curing at lower temperatures.

Organic fertilizers. Feather meal [granular formulation; $\mathrm{pH}$ 5.1; electrical conductivity (EC) $3.0 \mathrm{dS} \cdot \mathrm{m}^{-1}$ ] was applied by hand around the base of the plants in two equal applications on 3 Apr. and 16 May in 2007 and on 4 Mar. and 22 Apr. in 2008. Fish emulsion ( $\mathrm{pH}$ 5.5; EC $29.0 \mathrm{dS} \cdot \mathrm{m}^{-1}$ ) was applied every 2 weeks from 16 Apr. to 9 July in 2007 and from 15 Apr. to 8 July in 2008. The emulsion was diluted with 10 parts water just before each application. In late June 2007, plants fertilized with feather meal looked stressed; growth was poor and the leaves were turning red. Tissue analysis on 12 July confirmed that plants fertilized with feather meal had low leaf N levels of 11 to $15 \mathrm{~g} \cdot \mathrm{kg}^{-1}$. Plants fertilized with fish emulsion, in comparison, had leaf levels of 23 to $28 \mathrm{~g} \cdot \mathrm{kg}^{-1} \mathrm{~N}$. The feather meal treatments were thus fertilized with an additional $4 \mathrm{~kg} \cdot \mathrm{ha}^{-1} \mathrm{~N}$ of fish emulsion on 28 June and on 5 July 2007 to ensure plant survival; the fertilizer was diluted in water (1:10) and applied as a liquid soil drench above the root zone. The extra $\mathrm{N}$ was applied as fish emulsion because summer rainfall in Oregon is typically insufficient to dissolve granular fertilizers such as feather meal. There was only $16 \mathrm{~mm}$ of rain at the site in July 2007 and $17 \mathrm{~mm}$ in August. The plants improved considerably in appearance within 2 weeks after the extra fertilizer was applied, and by Aug. 2007, leaf $\mathrm{N}$ concentration was within or above the normal range for blueberry (18 to $20 \mathrm{~g} \cdot \mathrm{kg}^{-1} \mathrm{~N}$; Hart et al., 2006). Feather meal was applied 1 month earlier the next year to give the product more time to wash in with the rain.

Plant management. Two-year-old containergrown $(4 \mathrm{~L})$ plants were transplanted on 9 Oct. 2006. Plants were pruned immediately after planting to remove flower buds and shape the bushes. Most flower buds were also removed during pruning in January the next year to encourage shoot growth and limit crop production to $\approx 0.5 \mathrm{~kg} /$ plant in Year 2. Plants were irrigated from May to September, as needed, using a single lateral of drip tubing located on top of sawdust mulch or two laterals (for extra water) under the weed mat (see Larco, 2010, for details). The drip lines had $1.9-\mathrm{L} \cdot \mathrm{h}^{-1}$ in-line emitters

Table 1. Chemical, physical, and biological analysis (dry weight basis) of Willamette silty loam soil, douglas fir sawdust, and yard debris compost. $^{2}$

\begin{tabular}{|c|c|c|c|}
\hline Analysis & Soill $^{\mathrm{y}}$ & Sawdust & Compost \\
\hline pH (1:5, sample:water) & 4.9 & 4.2 & 7.3 \\
\hline \multicolumn{4}{|l|}{ Carbon and nitrogen } \\
\hline $\mathrm{C}: \mathrm{N}$ ratio & - & 437 & 21 \\
\hline Organic $\mathrm{C}\left(\mathrm{g} \cdot \mathrm{kg}^{-1}\right)$ & 16 & 481 & 230 \\
\hline $\begin{array}{l}\text { Organic matter } \\
\left(\mathrm{g} \cdot \mathrm{kg}^{-1}\right)\end{array}$ & 37 & 990 & 478 \\
\hline $\operatorname{Ash}\left(\mathrm{g} \cdot \mathrm{kg}^{-1}\right)$ & - & 10 & 522 \\
\hline Total N (g.kg $\left.\mathrm{kg}^{-1}\right)$ & 1.0 & 1.1 & 11 \\
\hline \multicolumn{4}{|l|}{$\begin{array}{l}\text { Available N } \\
\left(\mathrm{mg} \cdot \mathrm{kg}^{-1}\right)\end{array}$} \\
\hline $\mathrm{NH}_{4}-\mathrm{N}$ & 3.9 & 3.7 & 5 \\
\hline $\mathrm{NO}_{3}-\mathrm{N}$ & 11 & 1.6 & 16 \\
\hline \multicolumn{4}{|l|}{ Other total nutrients } \\
\hline $\mathrm{P}\left(\mathrm{g} \cdot \mathrm{kg}^{-1}\right)$ & 0.1 & 0.3 & 2.4 \\
\hline $\mathrm{K}\left(\mathrm{g} \cdot \mathrm{kg}^{-1}\right)$ & 0.3 & 0.05 & 5.6 \\
\hline $\mathrm{Ca}\left(\mathrm{g} \cdot \mathrm{kg}^{-1}\right)$ & 0.5 & 2.0 & 17.0 \\
\hline $\operatorname{Mg}\left(\mathrm{g} \cdot \mathrm{kg}^{-1}\right)$ & 0.1 & 0.3 & 5.4 \\
\hline $\mathrm{SO}_{4}-\mathrm{S}\left(\mathrm{mg} \cdot \mathrm{kg}^{-1}\right)$ & - & 39 & 1 \\
\hline $\mathrm{B}\left(\mathrm{mg} \cdot \mathrm{kg}^{-1}\right)$ & 0.1 & 2 & 8 \\
\hline $\mathrm{Cu}\left(\mathrm{mg} \cdot \mathrm{kg}^{-1}\right)$ & - & 5 & 75 \\
\hline $\mathrm{Mn}\left(\mathrm{mg} \cdot \mathrm{kg}^{-1}\right)$ & 16 & 61 & 540 \\
\hline $\mathrm{Zn}\left(\mathrm{mg} \cdot \mathrm{kg}^{-1}\right)$ & 0.6 & 11 & 183 \\
\hline $\mathrm{EC}\left(1: 5 ; \mathrm{dS} \cdot \mathrm{m}^{-1}\right)$ & $<1$ & $<1$ & $<1$ \\
\hline $\begin{array}{l}\text { Respiration } \\
\qquad\left(\mathrm{mg} \mathrm{CO}_{2}-\mathrm{C} / \mathrm{g} \mathrm{C} / \mathrm{d}\right)^{\mathrm{x}}\end{array}$ & - & 4.6 & 2.7 \\
\hline Bulk density $\left(\mathrm{kg} \cdot \mathrm{m}^{-3}\right)$ & 一 & 128 & 368 \\
\hline \multicolumn{4}{|l|}{ Particle size $(\%)$} \\
\hline Greater than $16 \mathrm{~mm}$ & - & 0 & 0 \\
\hline $4-16 \mathrm{~mm}$ & - & 20 & 37 \\
\hline $2-4 \mathrm{~mm}$ & - & 24 & 12 \\
\hline Less than $2 \mathrm{~mm}$ & - & 56 & 51 \\
\hline
\end{tabular}

${ }^{\mathrm{z}}$ Sawdust and compost were analyzed following the methods described in Thompson et al. (2001). ${ }^{\mathrm{y}}$ Measured 16 Aug. 2012 (pre-plant).

${ }^{x}$ Respiration was measured on samples pretreated with complete nutrient solution and incubated $72 \mathrm{~h}$ at $37^{\circ} \mathrm{C}$.

$\mathrm{C}=$ carbon; $\mathrm{N}=$ nitrogen; $\mathrm{P}=$ phosphorus; $\mathrm{K}=$ potassium; $\mathrm{Ca}=$ calcium $; \mathrm{Mg}=$ magnesium; $\mathrm{B}=$ boron; $\mathrm{Cu}=$ copper; $\mathrm{Mn}=$ manganese $\mathrm{Zn}=$ zinc; $\mathrm{EC}=$ electrical conductivity. 
spaced every $0.3 \mathrm{~m}$. Weeds were managed in all treatment plots, as needed, using organically approved methods and products (Julian et al., 2012; Larco et al., 2013).

Plant and soil nutrient analysis. Leaf samples were collected from three replicates per treatment in early August each year per recommended standards (Hart et al., 2006). Fifty leaves per plot were collected in the morning by removing fully expanded leaves at nodes 4, 5, and 6; sampling was done on all sides of the plants and vigorously growing whips were avoided. Leaf $\mathrm{N}$ was determined

using a combustion analyzer with an induction furnace and a thermal conductivity detector (Gavlak et al., 1994). Other nutrients, including $\mathrm{P}, \mathrm{K}, \mathrm{Ca}, \mathrm{Mg}, \mathrm{B}, \mathrm{Cu}, \mathrm{Mn}$, and $\mathrm{Zn}$, were determined using an inductively coupled plasma (ICP) spectrophotometer after wet ashing the samples in nitric/ perchloric acid (Gavlak et al., 1994). The analyses were done at the Oregon State University Central Analytical Laboratory in Corvallis, OR, in 2007 and at Brookside Laboratories, Inc. in New Bremen, $\mathrm{OH}$, in 2008.

Table 2. Total nutrients applied as mulch and fertilizer to a new planting of organic blueberry in Aurora, $\mathrm{OR}^{\mathrm{z}}$

\begin{tabular}{|c|c|c|c|c|c|c|c|c|c|}
\hline \multirow[b]{2}{*}{ Source } & \multicolumn{5}{|c|}{ Macronutrients $\left(\mathrm{kg} \cdot \mathrm{ha}^{-1}\right)$} & \multicolumn{4}{|c|}{ Micronutrients $\left(\mathrm{kg} \cdot \mathrm{ha}^{-1}\right)$} \\
\hline & $\mathrm{N}$ & $\mathrm{P}$ & $\mathrm{K}$ & $\mathrm{Ca}$ & $\mathrm{Mg}$ & $\mathrm{B}$ & $\mathrm{Cu}$ & $\mathrm{Mn}$ & $\mathrm{Zn}$ \\
\hline \multicolumn{10}{|l|}{$\overline{\text { Mulch }^{y}}$} \\
\hline Sawdust & 51 & 14 & 2 & 92 & 14 & 0.1 & 0.2 & 2.8 & 0.5 \\
\hline Compost & 615 & 134 & 313 & 951 & 302 & 0.4 & 4.2 & 30.2 & 10.2 \\
\hline \multicolumn{10}{|l|}{ Fertilizer $^{x}$} \\
\hline Feather meal & & & & & & & & & \\
\hline Low $\mathrm{N}$ rate & 29 & 4 & 0.4 & 6 & 0.6 & 7 & 2 & 10 & 27 \\
\hline High $\mathrm{N}$ rate & 57 & 8 & 0.8 & 12 & 1.2 & 14 & 4 & 20 & 54 \\
\hline Fish emulsion & & & & & & & & & \\
\hline Low $\mathrm{N}$ rate & 29 & 11 & 41 & 0.5 & 0.4 & 1 & 120 & 2 & 26 \\
\hline High $\mathrm{N}$ rate & 57 & 22 & 82 & 1.0 & 0.8 & 2 & 240 & 4 & 52 \\
\hline
\end{tabular}

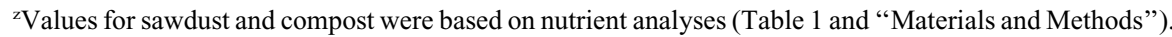
Values for feather meal and fish emulsion (Fish-Agra) were obtained from the product label. Feather meal was a granular product applied around the plants. Fish-Agra was a hydrolyzed fish product mixed 1:10 (v/ v) with water before application around plants. Note that an additional $8 \mathrm{~kg} \cdot \mathrm{ha}^{-1}$ of $\mathrm{N}$ from fish emulsion was applied with the feather meal in 2007 only ("Materials and Methods").

${ }^{y}$ Douglas fir sawdust was applied at a rate of $360 \mathrm{~m}^{3} \cdot \mathrm{ha}^{-1}$. Yard debris compost was applied at a rate of 152 $\mathrm{m}^{3} \cdot \mathrm{ha}^{-1}$ and covered with $200 \mathrm{~m}^{3} \cdot \mathrm{ha}^{-1}$ of sawdust (not included in total compost nutrients). Each was applied at planting in Oct. 2006.

${ }^{\mathrm{x}}$ Applied in two (feather meal) or five (fish emulsion) split applications in Spring 2007 and Spring 2008 $\mathrm{N}=$ nitrogen; $\mathrm{P}=$ phosphorus; $\mathrm{K}=$ potassium; $\mathrm{Ca}=$ calcium; $\mathrm{Mg}=$ magnesium; $\mathrm{B}=$ boron; $\mathrm{Cu}=$ copper; $\mathrm{Mn}=$ manganese $; \mathrm{Zn}=$ zinc.
Soil samples were collected on 5 Nov. 2008 in all 'Duke' treatments ('Liberty' was not sampled to reduce cost). Samples were collected to a depth of $0.2 \mathrm{~m}$ (after removing surface mulch) at $\approx 30 \mathrm{~cm}$ in row from the base of a plant in each plot. The soil was airdried and screened through 2-mm mesh before sending the samples to Brookside Laboratories for analysis. Soil $\mathrm{pH}$ was determined using a standard 1:1 soil:water method (McLean, 1982), and soil organic matter content was measured based on Loss-OnIgnition at $360{ }^{\circ} \mathrm{C}$ (Nelson and Sommers, 1996). Soil $\mathrm{NH}_{4}$ - and $\mathrm{NO}_{3}-\mathrm{N}$ were determined using an automated colorimetric method after extraction with $1 \mathrm{M} \mathrm{KCl}$ (Dahnke, 1990). Soil P (Bray II extraction), K, Ca, Mg, sodium, B, $\mathrm{Cu}, \mathrm{Mn}$, and $\mathrm{Zn}$ were determined by ICP after extraction using the Mehlich 3 method (Mehlich, 1984).

Statistical analysis. Analysis of all treatment effects was done as a complete factorial for a split-split plot design using the PROC MIXED procedure in SAS software Version 8 (SAS Institute, Cary, NC). Data were logtransformed as needed to improve homogeneity of variance. Orthogonal contrasts were used to compare source (fish vs. feather) and rate (low vs. high) of fertilizer and type of mulch ["organic" (sawdust and compost + sawdust) vs. weed mat; and sawdust vs. compost + sawdust]. Means were separated at the 0.05 level using Tukey's honestly significant difference test.

\section{Results}

Pre-plant soil conditions. Soil at the site had a $\mathrm{pH}$ of 4.9 before planting and contained

Table 3. Effects of bed type, organic fertilizer, and mulch on soil pH, organic matter (OM), and nutrient content in plots with 'Duke' blueberry. ${ }^{2}$

\begin{tabular}{|c|c|c|c|c|c|c|c|c|c|c|c|c|}
\hline \multirow[b]{3}{*}{ Treatment } & \multirow[b]{3}{*}{ Soil $\mathrm{pH}$} & \multirow[b]{3}{*}{ Soil OM $(\%)$} & \multicolumn{10}{|c|}{ Soil nutrients } \\
\hline & & & \multicolumn{3}{|c|}{----------(mg.kg $\left.{ }^{-1}\right)$--------- } & \multicolumn{3}{|c|}{------ meq/100 g soil -------- } & \multicolumn{4}{|c|}{----------------- $\left(\mathrm{mg} \cdot \mathrm{kg}^{-1}\right)$---------------- } \\
\hline & & & $\mathrm{NH}_{4}-\mathrm{N}$ & $\mathrm{NO}_{3}-\mathrm{N}$ & $\mathrm{P}$ & $\mathrm{K}$ & $\mathrm{Ca}$ & $\mathrm{Mg}$ & $\mathrm{B}$ & $\mathrm{Cu}$ & $\mathrm{Mn}$ & $\mathrm{Zn}$ \\
\hline \multicolumn{13}{|l|}{ Fertilizer } \\
\hline Feather meal (low N) & $5.4 \mathrm{a}^{\mathrm{y}}$ & - & $3 \mathrm{bc}$ & $2 \mathrm{c}$ & - & $0.6 \mathrm{~b}$ & $4.4 \mathrm{a}$ & - & - & - & $21 \mathrm{~b}$ & - \\
\hline Feather meal (high N) & $5.3 \mathrm{a}$ & - & $4 \mathrm{~b}$ & $3 \mathrm{~b}$ & - & $0.6 \mathrm{~b}$ & $4.1 \mathrm{ab}$ & - & - & - & $21 \mathrm{~b}$ & - \\
\hline Fish emulsion (low N) & $5.1 \mathrm{~b}$ & - & $2 \mathrm{c}$ & $2 \mathrm{bc}$ & - & $0.8 \mathrm{a}$ & $3.6 \mathrm{~b}$ & - & - & - & $22 \mathrm{~b}$ & - \\
\hline Fish emulsion (high $\mathrm{N}$ ) & $4.8 \mathrm{c}$ & - & $10 \mathrm{a}$ & $19 \mathrm{a}$ & - & $0.9 \mathrm{a}$ & $3.6 \mathrm{~b}$ & - & - & - & $30 \mathrm{a}$ & - \\
\hline \multicolumn{13}{|l|}{ Mulch } \\
\hline Sawdust & $5.3 \mathrm{~b}$ & $3.6 \mathrm{~b}$ & $2 b$ & $2 \mathrm{c}$ & $271 \mathrm{~b}$ & $0.6 \mathrm{~b}$ & $3.8 \mathrm{~b}$ & $1.2 \mathrm{ab}$ & $0.2 \mathrm{~b}$ & $0.7 \mathrm{~b}$ & $25 \mathrm{a}$ & $1 \mathrm{~b}$ \\
\hline Compost + sawdust & $5.5 \mathrm{a}$ & $4.7 \mathrm{a}$ & $3 \mathrm{~b}$ & $5 \mathrm{~b}$ & $280 \mathrm{a}$ & $1.0 \mathrm{a}$ & $5.0 \mathrm{a}$ & $1.6 \mathrm{a}$ & $0.3 \mathrm{a}$ & $0.9 \mathrm{a}$ & $21 \mathrm{~b}$ & $3 \mathrm{a}$ \\
\hline Weed mat & $4.8 \mathrm{c}$ & $3.6 \mathrm{~b}$ & $9 \mathrm{a}$ & $12 \mathrm{a}$ & $274 \mathrm{ab}$ & $0.6 \mathrm{~b}$ & $3.0 \mathrm{c}$ & $0.8 \mathrm{~b}$ & $0.2 \mathrm{~b}$ & $0.7 \mathrm{~b}$ & $24 \mathrm{a}$ & $1 \mathrm{~b}$ \\
\hline \multicolumn{13}{|l|}{ Significance $^{\mathrm{x}}$} \\
\hline \multicolumn{13}{|l|}{ Main-plot analysis } \\
\hline Bed type (B) & 0.8787 & 0.2728 & 0.6587 & 0.3033 & 0.6025 & 0.9597 & 0.8979 & 0.6356 & 0.9609 & 0.2737 & 0.1992 & 0.3963 \\
\hline \multicolumn{13}{|l|}{ Subplot analysis } \\
\hline Fertilizer (F) & $<0.0001$ & 0.7893 & $<0.0001$ & $<0.0001$ & 0.2624 & $<0.0001$ & 0.0182 & 0.4194 & 0.3751 & 0.9780 & $<0.0001$ & 0.1598 \\
\hline $\mathrm{B} \times \mathrm{F}$ & 0.6763 & 0.9815 & 0.1006 & 0.7978 & 0.8460 & 0.8193 & 0.6811 & 0.6287 & 0.2338 & 0.8441 & 0.8936 & 0.4288 \\
\hline \multicolumn{13}{|l|}{ Sub-subplot analysis } \\
\hline Mulch (M) & $<0.0001$ & $<0.0001$ & $<0.0001$ & $<0.0001$ & 0.0067 & $<0.0001$ & $<0.0001$ & $<0.0001$ & $<0.0001$ & $<0.0001$ & 0.0053 & $<0.0001$ \\
\hline $\mathrm{B} \times \mathrm{M}$ & 0.0557 & 0.3870 & 0.9850 & 0.1044 & 0.0652 & 0.2321 & 0.5658 & 0.1479 & 0.8231 & 0.6970 & 0.0271 & 0.0700 \\
\hline $\mathrm{F} \times \mathrm{M}$ & 0.3394 & 0.5872 & $<0.0001$ & 0.2012 & 0.0496 & 0.0373 & 0.7548 & 0.5842 & 0.0678 & 0.5930 & 0.4636 & 0.9292 \\
\hline $\mathrm{B} \times \mathrm{F} \times \mathrm{M}$ & 0.3854 & 0.9655 & 0.0934 & 0.2483 & 0.7402 & 0.1264 & 0.1807 & 0.3796 & 0.6537 & 0.8599 & 0.1997 & 0.7535 \\
\hline \multicolumn{13}{|l|}{ Contrasts } \\
\hline Feather vs. fish & $<0.0001$ & 0.3851 & 0.1797 & $<0.0001$ & 0.6128 & $<0.0001$ & 0.0032 & 0.1569 & 0.6699 & 0.8117 & $<0.0001$ & 0.5546 \\
\hline Low N vs. high $\mathrm{N}$ & 0.0037 & 0.7902 & $<0.0001$ & $<0.0001$ & 0.0888 & 0.3350 & 0.4370 & 0.6716 & 0.0954 & 0.9201 & 0.0004 & 0.0890 \\
\hline Weed mat vs. organic & $<0.0001$ & $<0.0001$ & $<0.0001$ & $<0.0001$ & 0.7088 & $<0.0001$ & $<0.0001$ & $<0.0001$ & 0.0080 & $<0.0001$ & 0.1878 & $<0.0001$ \\
\hline Sawdust vs. compost & 0.0115 & $<0.0001$ & 0.7241 & 0.0005 & 0.0017 & $<0.0001$ & $<0.0001$ & $<0.0001$ & $<0.0001$ & $<0.0001$ & 0.0029 & $<0.0001$ \\
\hline
\end{tabular}

${ }^{\mathrm{z}}$ Soil was sampled (0-0.2 $\mathrm{m}$ deep) in Nov. 2008 after the second year after planting.

${ }^{y}$ Means followed by the same letter, within treatments, are not significantly different $(P>0.05$, using Tukey's honestly significant difference test).

${ }^{\mathrm{x}}$ Treatments that are significantly different $(P<0.05)$ are bolded for ease of reference.

$\mathrm{P}=$ phosphorus $\mathrm{K}=$ potassium; $\mathrm{Ca}=$ calcium; $\mathrm{Mg}$ = magnesium; $\mathrm{B}=$ boron; $\mathrm{Cu}=$ copper; $\mathrm{Mn}=$ manganese; $\mathrm{Zn}=$ zinc . 
$3.7 \%$ organic matter (Table 1). Soil analysis indicated that the only nutrient aside from $\mathrm{N}$ considered low was B (less than $0.5 \mathrm{mg} \cdot \mathrm{kg}^{-1}$; Horneck et al., 2011). All other soil nutrients were within or above the range recommended for blueberry.

Characteristics of the organic mulch and fertilizers applied at planting. The sawdust used in the study had a low $\mathrm{pH}$, a high $\mathrm{C}: \mathrm{N}$ ratio, and a limited amount of many nutrients, including available $\mathrm{N}$ (Table 1). The compost, on the other hand, had a high $\mathrm{pH}$, a low $\mathrm{C}: \mathrm{N}$ ratio, and a high amount of many nutrients but was also low in available $\mathrm{N}$ $\left(\approx 10 \mathrm{~g} \cdot \mathrm{kg}^{-1}\right)$. Approximately half of the compost dry matter was dry ash (52\%). The compost was highly stable (i.e., low microbial respiration) and low in salinity (EC less than $1.0 \mathrm{dS} \cdot \mathrm{m}^{-1}$ ), and although it had a similar percentage of fine particles as sawdust (less than $2 \mathrm{~mm}$ ), it had three times the bulk density. Based on the amount applied at planting, the compost mulch contained 0.6 t.ha ${ }^{-1} \mathrm{~N}, 0.1 \mathrm{t} \cdot \mathrm{ha}^{-1} \mathrm{P}, 0.3 \mathrm{t} \cdot \mathrm{ha}^{-1} \mathrm{~K}$ and $\mathrm{Mg}$, $1.0 \mathrm{t} \cdot \mathrm{ha}^{-1} \mathrm{Ca}$, and a total of $45 \mathrm{~kg} \cdot \mathrm{ha}^{-1}$ of micronutrients, including $\mathrm{B}, \mathrm{Cu}, \mathrm{Mn}$, and $\mathrm{Zn}$ (Table 2). The sawdust mulch, in comparison, contained less than $0.2 \mathrm{t} \cdot \mathrm{ha}^{-1}$ of total macronutrients and only $3.6 \mathrm{~kg} \cdot \mathrm{ha}^{-1}$ of micronutrients (Mn and $\mathrm{Zn}$ only).

The organic fertilizers used in the study also differed in total nutrients (Table 2). Although both were applied at the same low and high rates of $\mathrm{N}\left(29\right.$ and $\left.57 \mathrm{~kg} \cdot \mathrm{ha}^{-1}\right)$, feather meal contained more $\mathrm{Ca}, \mathrm{B}$, and $\mathrm{Mn}$, whereas fish emulsion contained more $\mathrm{P}, \mathrm{K}$, and $\mathrm{Cu}$. Fish emulsion also contained 10 times more soluble salts than feather meal (see EC values in "Materials and Methods") but was diluted, as already mentioned, to $10 \%$ with water before application.

Differences in soil conditions associated with the use of the fertilizers and mulches. Soil conditions were very similar between the two bed types, after the second year after planting, but differed with type and rate of fertilizer applied and with the kind of mulch used (Table 3 ). Many of the soil measurements, including $\mathrm{pH}, \mathrm{NH}_{4}-\mathrm{N}, \mathrm{NO}_{3}-\mathrm{N}, \mathrm{K}, \mathrm{Ca}$, and $\mathrm{Mn}$, were significantly affected by fertilizer. All soil variables measured were significantly affected by mulch.

Soil $\mathrm{pH}$ was lower with fish emulsion than with feather meal, especially when a high rate of fish emulsion was applied, and was higher with organic mulch than with weed mat, especially when compost was applied (Table 3). Soil mulched with compost also had 11 $\mathrm{g} \cdot \mathrm{kg}^{-1}$ more organic matter than soil with sawdust or weed mat and contained $10 \mathrm{~g} \cdot \mathrm{kg}^{-1}$ more organic matter than the soil measured before planting (Tables 1 and 3).

Among the soil nutrients, $\mathrm{NH}_{4}-\mathrm{N}, \mathrm{NO}_{3}-\mathrm{N}$, and $\mathrm{Mn}$ were higher when plants were fertilized with a high rate of fish emulsion than with a low rate of fish emulsion or either rate of feather meal (Table 3). Soil K was also higher with fish emulsion than with feather meal but, in this case, was unaffected by the rate at which either fertilizer was applied. Soil $\mathrm{Ca}$, on the other hand, was higher with feather meal than with fish emulsion, but only when the low rate of feather meal was applied.

Most of the soil nutrients, including $\mathrm{P}, \mathrm{K}$, $\mathrm{Ca}, \mathrm{Mg}, \mathrm{B}, \mathrm{Cu}$, and $\mathrm{Zn}$, were higher under compost than with either or both of the other mulches, whereas soil $\mathrm{NH}_{4}$ - and $\mathrm{NO}_{3}-\mathrm{N}$ were higher under weed mat (Table 3). However, significant interactions with fertilizer indicated that: 1) soil $\mathrm{NH}_{4}-\mathrm{N}$ was only higher with weed mat when a high rate of fish emulsion was applied (Fig. 1A); 2) soil P was similar between compost + sawdust and sawdust alone when the high rate of feather meal was applied and similar between compost and weed mat when feather meal was applied (Fig. 1B); and 3) at the high rate of N, soil $\mathrm{K}$ was higher under sawdust than weed mat when feather meal was applied but the opposite was found for fish emulsion (Fig. 1C). The only soil nutrient that was lower with compost + sawdust than with either sawdust or weed mat was Mn (Table 3). The effect of mulch on soil Mn differed between bed types. Soil Mn was higher with sawdust $\left(27 \mathrm{mg} \cdot \mathrm{kg}^{-1}\right)$ than with weed mat (23 $\mathrm{mg} \cdot \mathrm{kg}^{-1}$ ) in flat beds, but the opposite was found in raised beds (i.e., $23 \mathrm{mg} \cdot \mathrm{kg}^{-1}$ with sawdust and $27 \mathrm{mg} \cdot \mathrm{kg}^{-1}$ with weed mat).

Effects of bed type, fertilizer, and mulch on leaf nutrients. By Aug. 2007 (Year 1), leaf $\mathrm{N}$ concentration was highest, on average, when plants were fertilized with a high rate of fish emulsion and lowest when they were fertilized with either a low rate of fish emulsion or a high rate of feather meal (Table 4). However, as mentioned in the "Materials and Methods," plants fertilized with feather meal (low and high rate) had poor growth and low leaf $\mathrm{N}$ levels in late June in Year 1 and therefore were fertilized with two small applications of diluted fish emulsion; a total of $8 \mathrm{~kg} \cdot \mathrm{ha}^{-1}$ of extra $\mathrm{N}$ was applied. Leaf $\mathrm{N}$ was affected by numerous treatment interactions, including a four-way interaction among bed type, fertilizer, mulch, and cultivar. Specifically, leaf $\mathrm{N}$ was higher with weed mat than with sawdust or compost + sawdust mulch but only in 'Duke' on flat beds fertilized with fish emulsion (Fig. 2A), 'Liberty' on flat beds fertilized with a low rate of feather meal or either rate of fish emulsion (Fig. 2C), or 'Liberty' on raised beds fertilized with a low rate of fish emulsion (Fig. 2D). Also, leaf $\mathrm{N}$ was unaffected by mulch in 'Duke' on raised beds (Fig. 2B) and was higher with sawdust than with weed mat in 'Liberty' on raised beds fertilized with a low rate of feather meal (Fig. 2D).

Leaf $\mathrm{P}$ was also affected in Year 1 by a four-way interaction among the treatments (Table 4). The level was higher with weed mat than with sawdust or compost in 'Duke' on flat beds fertilized with a high rate of feather meal (Fig. 2E) or in 'Liberty' on flat beds fertilized with a low rate of feather meal or fish emulsion (Fig. 2G) but was higher with sawdust in 'Liberty' on raised beds fertilized with either rate of feather meal (Fig. 2H). Contrast analysis indicated that leaf $\mathrm{P}$ was also higher, on average, with feather meal than with fish emulsion (Table 4).
Leaf cations also differed, in general, among fertilizer and mulch treatments in Year 1 and were affected by significant interactions between bed type and fertilizer (Ca only), bed type and mulch ( $\mathrm{K}$ and $\mathrm{Mg}$ only), bed type and cultivar ( $\mathrm{Ca}$ and $\mathrm{Mg}$ only), fertilizer and mulch, fertilizer and cultivar, and mulch and cultivar (Table 4). Leaf $\mathrm{K}$ was basically higher with weed mat or compost than with sawdust when plants were grown on flat beds but not on raised beds Plants grown with sawdust had a low leaf K, and those grown on weed mat and fertilized with the high rate of fish emulsion had particularly high leaf $\mathrm{K}$ (Fig. 2I). Leaf $\mathrm{Ca}$ and $\mathrm{Mg}$, on the other hand, were higher with feather meal than with fish emulsion, particularly in 'Duke' (Table 4) and when plants were mulched with sawdust (Fig. 2J-K).
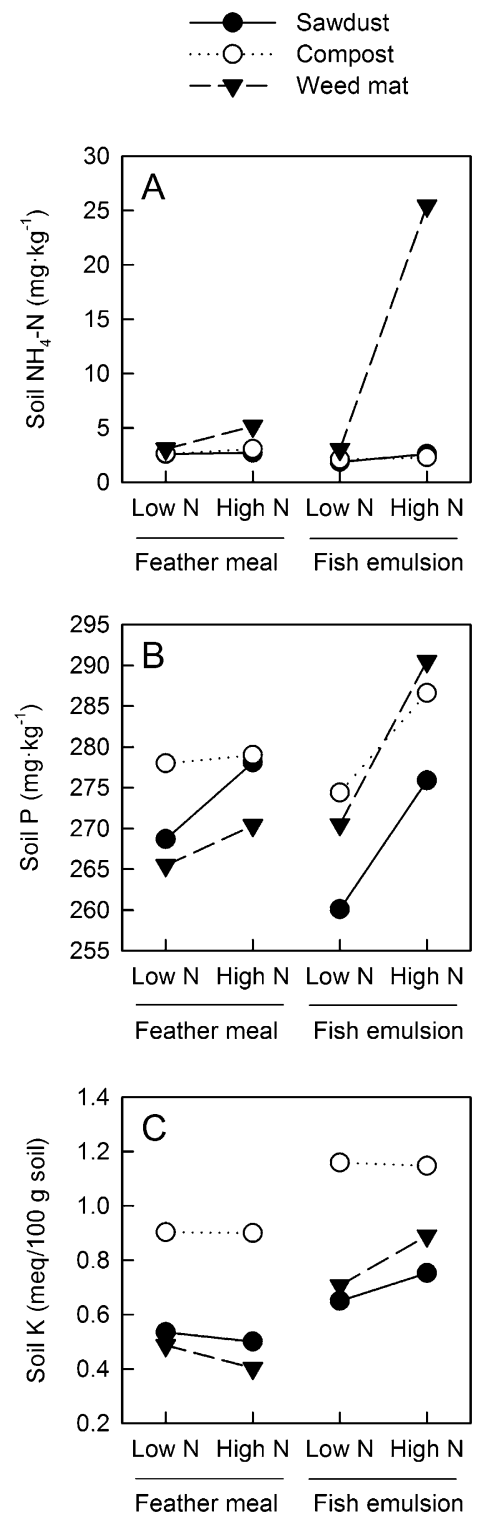

Fig. 1. Interaction effects of organic fertilizer and mulch on soil $\mathrm{NH}_{4}-\mathrm{N}(\mathbf{A})$, phosphorus (P) (B), and potassium $(\mathrm{K})(\mathbf{C})$ in plots with 'Duke' blueberry after the second year after planting, Nov. 2008. 


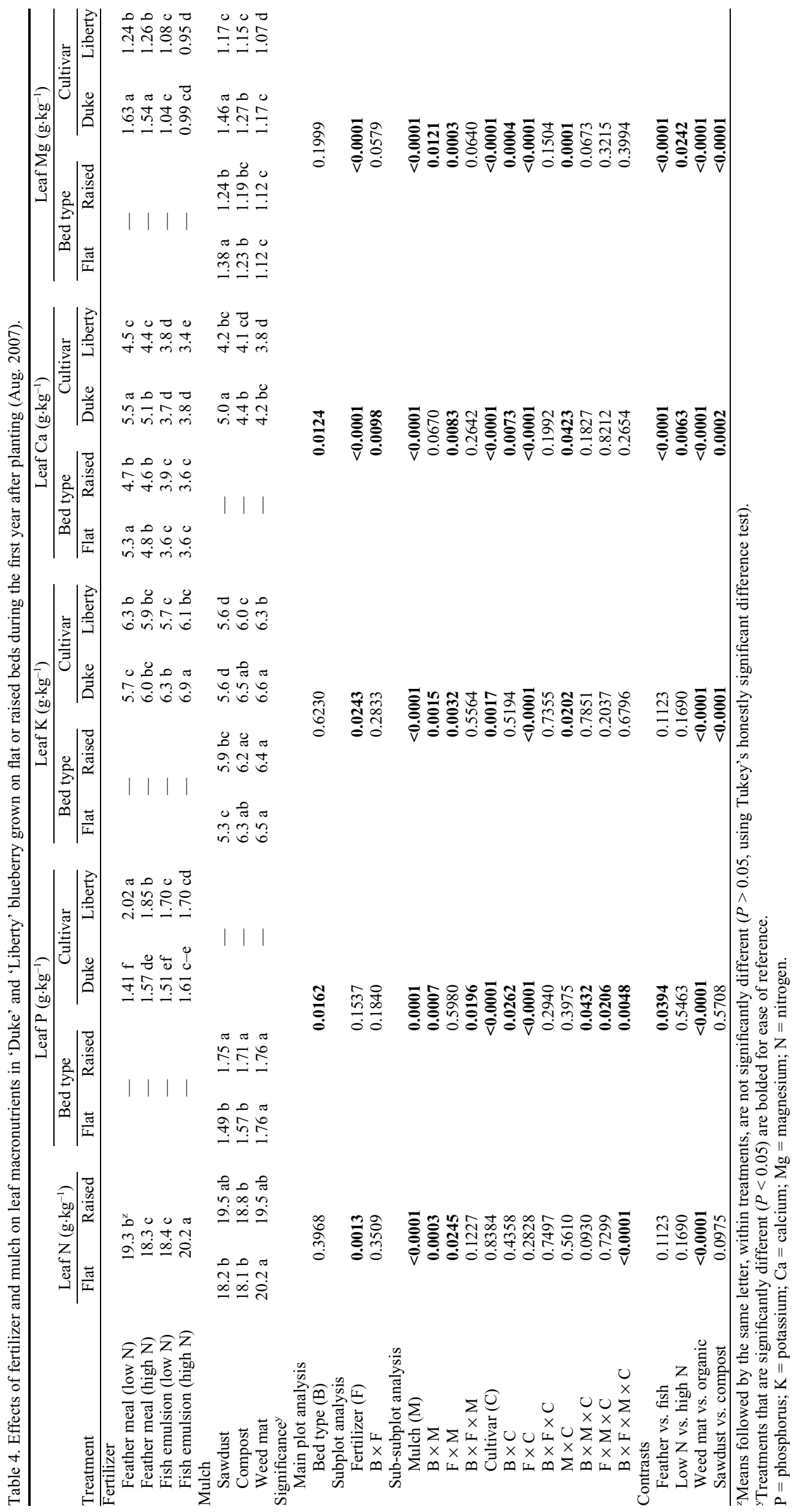



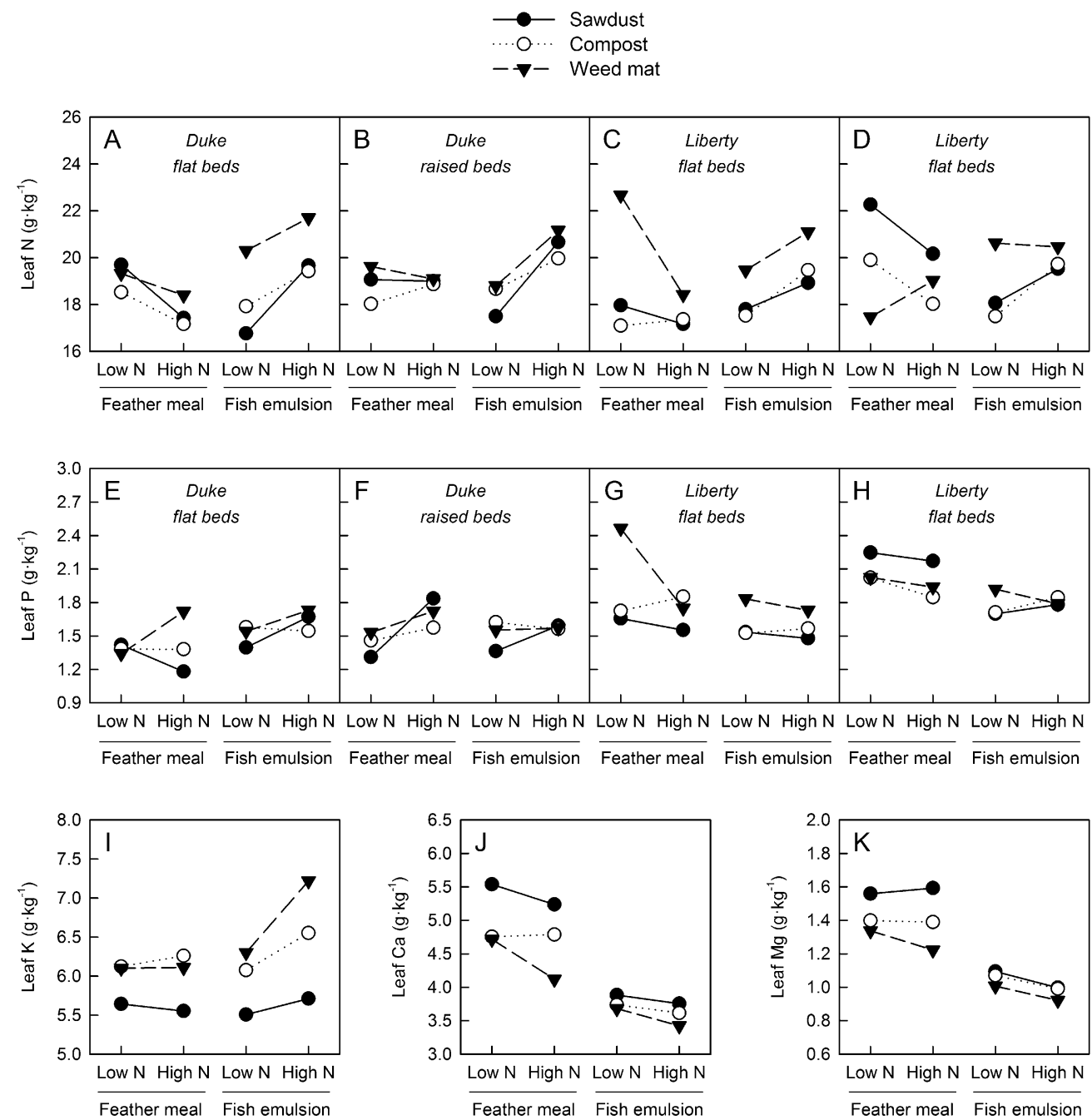

Fig. 2. Interaction effects of organic fertilizer and mulch on leaf nitrogen $(\mathrm{N})(\mathbf{A}-\mathbf{D})$, phosphorus $(\mathrm{P})(\mathbf{E}-\mathbf{H})$, potassium $(\mathrm{K})(\mathbf{I})$, calcium $(\mathrm{Ca})(\mathbf{J})$, and magnesium $(\mathrm{Mg})(\mathbf{K})$ concentration in 'Duke' and 'Liberty' on flat and raised planting beds blueberry during the first year after planting, Aug. 2007.

Leaf micronutrients were likewise affected by fertilizer and mulch in Year 1, but only leaf $\mathrm{Mn}$ and $\mathrm{Zn}$ were affected by interactions with bed type (Table 5). Like Ca and $\mathrm{Mg}$, leaf $\mathrm{B}$ was higher with feather meal than with fish emulsion but lower with weed mat when either rate of feather meal was applied (Fig. 3A), whereas leaf $\mathrm{Cu}$ was only affected by fertilizer (and cultivar; 6.0 vs. 6.4 $\mathrm{mg} \cdot \mathrm{kg}^{-1} \mathrm{Cu}$ for 'Duke' and 'Liberty', respectively) and differed by less than 1 $\mathrm{mg} \cdot \mathrm{kg}^{-1}$ among the treatments (Table 5). Leaf $\mathrm{Mn}$ and $\mathrm{Zn}$, on other hand, differed considerably among treatments and were affected by four-way interactions among the treatments. Both were higher with feather meal than with fish emulsion, but like $\mathrm{N}$ and $\mathrm{P}$, the level of response varied depending on bed type, mulch, and cultivar (Fig. 3B-I).

Only leaf $\mathrm{Ca}, \mathrm{Mg}$, and $\mathrm{B}$ were below levels recommended for blueberry in Year 1 and only when plants were fertilized with fish emulsion (Hart et al., 2006). Shoot tip dieback, a symptom of B deficiency, was observed in a few plots, but symptoms were minimal and were not associated with any treatment in particular.
By Aug. 2008 (Year 2), leaf N, P, and K were highest when plants were fertilized with a high rate of fish emulsion and lowest with the low rate of feather meal (Table 6). Leaf $\mathrm{N}$ was also higher with sawdust or compost + sawdust than with weed mat, and all three nutrients differed between cultivars (1.73 and $1.98 \mathrm{~g} \cdot \mathrm{kg}^{-1} \mathrm{~N}$ in 'Liberty' and 'Duke', respectively). Leaf $\mathrm{Ca}$ was significantly affected by a three-way interaction among fertilizer, mulch, and cultivar, and leaf $\mathrm{Mg}$ was affected by fertilizer and an interaction between mulch and cultivar (Table 6). Like in the previous year, leaf $\mathrm{Ca}$ was higher, on average, with feather meal than with fish emulsion but varied depending on the mulch and cultivar (Fig. 4). For example, leaf $\mathrm{Ca}$ was higher with compost than with sawdust or weed mat in 'Duke' fertilized with a low rate of feather meal but higher with sawdust when plants were fertilized with a high rate of feather meal. Leaf $\mathrm{Ca}$ was also higher with sawdust or compost + sawdust than with weed mat in 'Duke' fertilized with either rate of fish emulsion or 'Liberty' fertilized with a high rate of feather meal. Leaf Mg continued to be higher, on average, with feather meal than with fish emulsion, but levels were now similar between the high rate of feather meal and the low rate of fish emulsion (Table 6). Leaf $\mathrm{Mg}$ was also higher with sawdust or compost than with weed mat, but only in 'Duke'.

Leaf B was lower, on average, in Year 2 than in the previous year but once again was higher with feather meal than with fish emulsion (Tables 5 and 7). Leaf B continued to be higher with compost than with weed mat but in 2008 was similar between sawdust and weed mat. Leaf $\mathrm{Cu}$ no longer differed with fertilizer but varied with mulch. Leaf $\mathrm{Cu}$ was lower with weed mat than with sawdust or compost + sawdust in 'Duke' but was higher with weed mat and different between sawdust and compost + sawdust in 'Liberty' (Table 7). Leaf Mn, on the other hand, was higher with fish emulsion than with feather meal in 2008 (opposite from the previous year) - particularly on flat beds and in 'Duke' - and was higher with weed mat than with other mulches on flat beds and higher with sawdust than with other mulches on raised beds (Table 7). Finally, leaf $\mathrm{Zn}$ varied again with fertilizer and mulch, as well as 
Table 5. Effects of fertilizer and mulch on leaf micronutrients in 'Duke' and 'Liberty' blueberry grown on flat or raised beds during the first year after planting (Aug. 2007).



${ }^{\mathrm{z}}$ Means followed by the same letter, within treatments, are not significantly different $(P>0.05$, using Tukey's honestly significant difference test).

${ }^{\mathrm{y}}$ Treatments that are significantly different $(P<0.05)$ are bolded for ease of reference.

$\mathrm{B}=$ boron; $\mathrm{Cu}=$ copper; $\mathrm{Mn}=$ manganese; $\mathrm{Zn}=$ zinc; $\mathrm{N}=$ nitrogen.

with interactions of bed type and cultivar, but in general was higher in 'Duke' than in 'Liberty' and greater with sawdust or compost + sawdust than with weed mat in 'Duke' or higher with sawdust than with weed mat in 'Liberty' in 2008.

Leaf $\mathrm{N}$ was low or deficient in some cases when feather meal was applied the second year, leaf B was low again in all treatments, and leaf $\mathrm{Cu}$ was marginal (Hart et al., 2006).

Leaf $\mathrm{K}$, on the other hand, was increasing and becoming marginally high with fish emulsion.

\section{Discussion}

Soil $\mathrm{pH}$ and organic matter. Soil $\mathrm{pH}$ was lowest with weed mat and highest when compost was applied. Similar results have been reported by others in blueberry and tree fruit (Burkhard et al., 2009; Choi et al., 2011; Neilsen et al., 2003). Soil temperatures are often warmer under weed mat, which likely increases nitrification (Sabey et al., 1956), an acidifying process. The yard debris compost, with a high $\mathrm{pH}$ and cation content (particularly $\mathrm{K}, \mathrm{Ca}$, and $\mathrm{Mg}$; Table 1) relative to the soil and applied sawdust, was expected to increase soil $\mathrm{pH}$. Fish emulsion also reduced soil $\mathrm{pH}$, particularly when the higher rate of fish fertilizer was applied. Nitrogen fertilizer application is the primary management practice that causes soil acidification (Hart et al., 2013).

Compost + sawdust mulch also increased soil organic matter from $3.7 \%$ to $4.7 \%$ within 2 years after planting. Sawdust and weed mat, in comparison, had little to no effect on soil organic matter during the same period. Although compost contained a lower percentage of organic matter than sawdust at application, the compost was more stable (less decomposition) and denser than the sawdust. Compost (dairy solids, manure, and straw) also increased soil organic matter content in a vegetable production system (Wedryk et al., 2012).

Soil and leaf nitrogen. Soil $\mathrm{N}\left(\mathrm{NH}_{4}-\right.$ and $\mathrm{NO}_{3}-\mathrm{N}$ ) was higher under weed mat than under sawdust or compost + sawdust in the present study. Soil $\mathrm{N}$ was also more available under weed mat than under organic mulch in apple [Malus ×sylvestris (L.) Mill. var. domestica (Borkh.) Mansf.] (Choi et al., 2011). Weed mat reduced soil $\mathrm{N}$ relative to bare soil after 5 years in cherry (Yin et al., 2007) and relative to shredded paper mulch or biosolids after 7 years in apple (Neilsen et al., 2003). Higher availability of soil N under weed mat appeared to result in higher leaf $\mathrm{N}$ levels during the first year but not during the second. Perhaps higher growth and production with weed mat diluted $\mathrm{N}$ and other nutrients in the plants and resulted in lower leaf $\mathrm{N}$ levels in Year 2 (Larco et al., 2013). Leaf $N$ was higher with weed mat than bare soil in cherry (Yin et al., 2007) but was unaffected by weed mat after 6 years in apple (Choi et al., 2011).

Mulching with compost + sawdust also increased soil $\mathrm{N}$ compared with sawdust alone but only by a total of $4 \mathrm{mg} \cdot \mathrm{kg}^{-1} \mathrm{~N}$, most of which was $\mathrm{NO}_{3}-\mathrm{N}$. Based on an estimated mineralization rate of $3 \%$ of total $\mathrm{N}$ annually, yard debris compost added $\approx 18$ $\mathrm{kg} \cdot \mathrm{ha}^{-1} \mathrm{~N}$ per year (Gale et al., 2006; Sikora and Szmidt, 2001). The additional $\mathrm{N}$ from the compost did not increase plant growth (Larco et al., 2013) or leaf $\mathrm{N}$ levels, however, and therefore may have been unavailable when needed in blueberry (Bañados et al., 2012). Others have found increased leaf $\mathrm{N}$ in blueberry with use of compost mulch (Burkhard et al., 2009) or variable effects of mulch depending on year (Krewer et al., 2009).

Leaf $\mathrm{N}$ in all treatments ranged from 18.3 to $20.2 \mathrm{~g} \cdot \mathrm{kg}^{-1}$ in Year 1 and 15.9 to 22.7 $\mathrm{g} \cdot \mathrm{kg}^{-1}$ in Year 2. The levels declined, on average, the second year, probably as a result of plant age and fruit production (Bryla et al., 2012; Cummings, 1978). Leaf $\mathrm{N}$ was also lower in 'Liberty' than in 'Duke'. Leaf $\mathrm{N}$ may have been diluted in 'Liberty' as a result of 1) production of more biomass by the cultivar (Larco et al., 2013); and 2) the later fruiting season as compared with 'Duke'. 

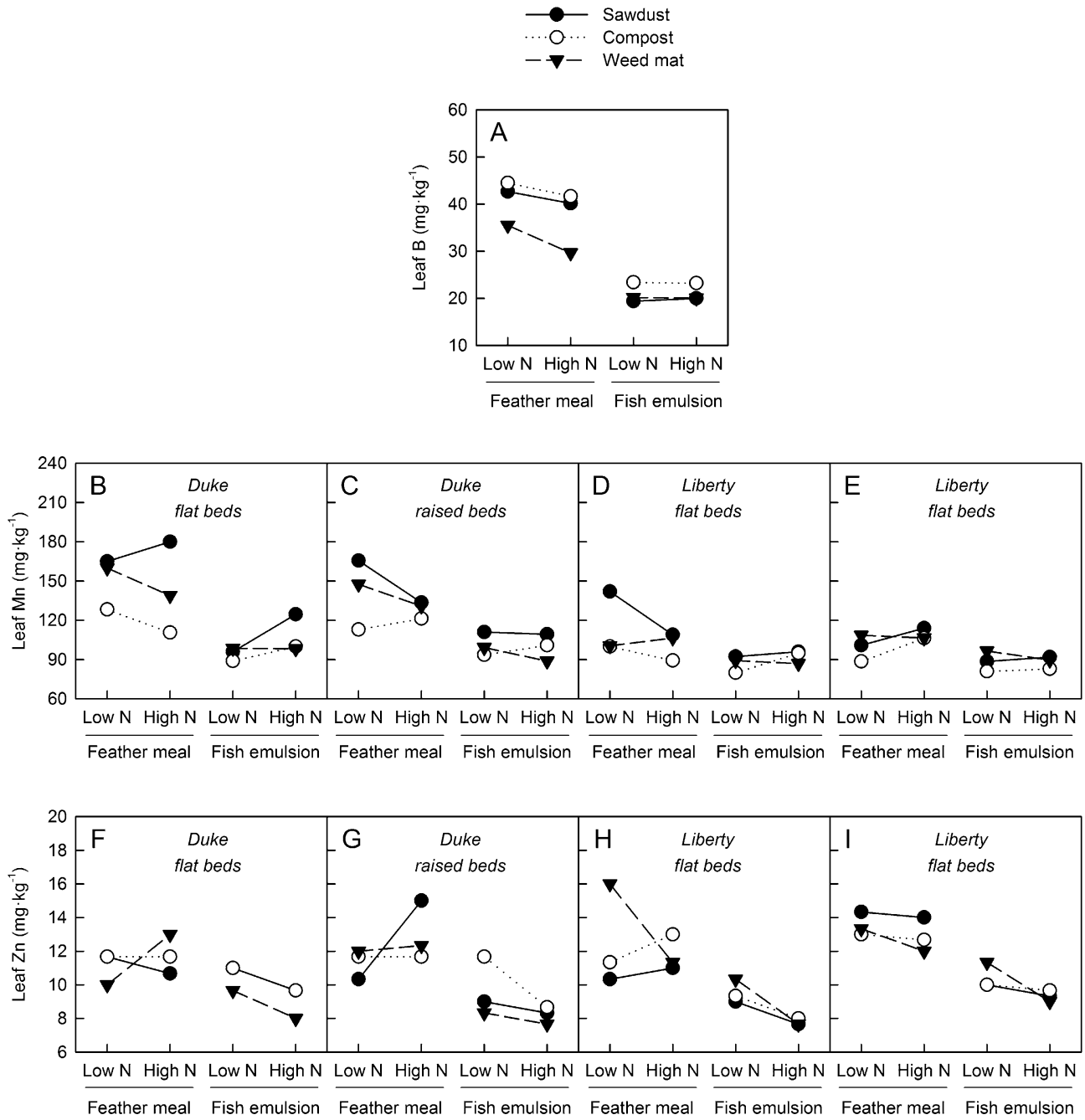

Fig. 3. Interaction effects of organic fertilizer and mulch on leaf boron (B) (A), manganese (Mn) (B-E), and zinc (Zn) (F-I) concentration in 'Duke' and 'Liberty' blueberry on flat and raised planting beds during the first year after planting, Aug. 2007.

Leaves were collected for nutrient analysis at the recommended time of sampling for northern highbush blueberry, but this was after harvest in 'Duke' and during harvest in 'Liberty'.

Leaf $\mathrm{N}$ levels were highest in plants fertilized with $57 \mathrm{~kg} \cdot \mathrm{ha}^{-1} \mathrm{~N}$ as fish emulsion and mulched with weed mat. Nitrogen was apparently more available when needed from the liquid fish emulsion than from the granular feather meal as evidenced by poor growth with feather meal during the first growing season (Larco et al., 2013). Higher leaf $\mathrm{N}$ was also found in plants fertilized with the higher rate of $\mathrm{N}$ as has been shown in young plants fertilized with inorganic forms of N (Bryla et al., 2012; Cummings et al., 1971). Leaf $\mathrm{N}$ was not positively correlated with yield, however, because plants fertilized with the high rate of fish emulsion had a lower yield than those fertilized with the low rate (Larco et al., 2013).

Soil and leaf phosphorus. Bed type had no effect on soil P, but leaf $\mathrm{P}$ was higher on raised beds than on flat beds in Year 1, except in plants with weed mat, where leaf P levels were high in both bed types. Phosphorus may have been more available in raised beds as a result of more root growth in the treatment (Larco et al., 2013) and higher under weed mat resulting from warmer soil temperatures (Cox, 2009; Larco, 2010). Temporary symptoms of $\mathrm{P}$ deficiency are a common problem in the spring in blueberry when soil temperatures are cooler (Strik, personal observation).

Compost also increased soil $\mathrm{P}$, but in contrast to the study by Burkhard et al. (2009), it had no effect on leaf P. Soil P was well above the recommended level in our study (Hart et al., 2006). Leaf P increased with fertilizer rate by the second year after planting. This may have been a response to the $P$ applied in the fertilizer products used, but leaf $\mathrm{P}$ levels have also been found to increase with higher application rates of $\mathrm{N}$ fertilizer (Bryla et al., 2012).

Soil and leaf cations. Soil $\mathrm{K}$ and Ca were higher with compost + sawdust than with sawdust alone or with weed mat, whereas soil $\mathrm{Ca}$ and $\mathrm{Mg}$ (but not $\mathrm{K}$ ) were higher with sawdust than with weed mat. This latter result for soil $\mathrm{Ca}$ and $\mathrm{Mg}$ is similar to what has been reported in orchard systems (Choi et al., 2011; Neilsen et al., 2003), but K was also higher with sawdust in cherry (Choi et al., 2011). Soil $\mathrm{K}$ and $\mathrm{Mg}$ were within recommended levels for blueberry, but soil Ca was below the recommended level with sawdust or weed mat (Hart et al., 2006).

In the first year, plants grown with sawdust mulch had the lowest leaf $\mathrm{K}$ and the highest leaf $\mathrm{Ca}$ and $\mathrm{Mg}$, particularly when fertilized with feather meal. In contrast, plants grown with weed mat had the highest leaf $\mathrm{K}$ and the lowest leaf $\mathrm{Mg}$ and $\mathrm{Ca}$, depending on the type of fertilizer applied. By the second year, weed mat reduced leaf $\mathrm{Mg}$ and $\mathrm{Ca}$ relative to sawdust and compost + sawdust. Mulching with compost + sawdust increased leaf $\mathrm{K}$ in both cultivars and reduced leaf $\mathrm{Ca}$ and $\mathrm{Mg}$ in 'Duke' in Year 1. Yin et al. (2007) also reported a lower leaf $\mathrm{Ca}$ and $\mathrm{Mg}$ in cherry grown with weed mat compared with bare soil. By the second year of our study, leaf $\mathrm{K}$ was still higher in compost + sawdust than in sawdust alone, but there was no significant difference between these mulches for leaf $\mathrm{Ca}$ and Mg. Burkhard et al. (2009) also reported higher leaf $\mathrm{K}$ with compost mulch than in bare soil. In our study, the K applied in the compost was quickly available to the 
Table 6. Effects of fertilizer and mulch on leaf macronutrients in 'Duke' and 'Liberty' blueberry grown on flat or raised beds during the second year after planting (Aug. 2008).

\begin{tabular}{|c|c|c|c|c|c|c|c|c|c|c|c|}
\hline \multirow{2}{*}{ Treatment } & \multirow{2}{*}{\multicolumn{2}{|c|}{ Leaf $N\left(g \cdot \mathrm{kg}^{-1}\right)$}} & \multirow{2}{*}{\multicolumn{2}{|c|}{ Leaf $P\left(\mathrm{~g} \cdot \mathrm{kg}^{-1}\right)$}} & \multicolumn{4}{|c|}{ Leaf $\mathrm{K}\left(\mathrm{g} \cdot \mathrm{kg}^{-1}\right)$} & \multirow{2}{*}{ Leaf Ca $\left(\mathrm{g} \cdot \mathrm{kg}^{-1}\right)$} & & \\
\hline & & & & & \multicolumn{2}{|c|}{ Bed type } & \multicolumn{2}{|c|}{ Cultivar } & & \multicolumn{2}{|c|}{ Leaf $\mathrm{Mg}\left(\mathrm{g} \cdot \mathrm{kg}^{-1}\right)$} \\
\hline \multicolumn{12}{|l|}{ Fertilizer } \\
\hline Feather meal (high $\mathrm{N}$ ) & $17.2 \mathrm{de}$ & $18.1 \mathrm{~cd}$ & $1.66 \mathrm{~b}$ & $1.20 \mathrm{~d}$ & $5.8 \mathrm{c}$ & $6.3 \mathrm{~b}$ & $6.5 \mathrm{c}$ & $5.7 \mathrm{e}$ & - & \multicolumn{2}{|c|}{$1.51 \mathrm{~b}$} \\
\hline Fish emulsion (low N) & $18.7 \mathrm{c}$ & $18.6 \mathrm{~cd}$ & $1.73 \mathrm{~b}$ & $1.27 \mathrm{~d}$ & $6.5 \mathrm{~b}$ & $6.6 \mathrm{~b}$ & $6.8 \mathrm{~b}$ & $6.3 \mathrm{~cd}$ & - & \multicolumn{2}{|c|}{$1.51 \mathrm{~b}$} \\
\hline Fish emulsion (high N) & $22.7 \mathrm{a}$ & $21.0 \mathrm{~b}$ & $1.97 \mathrm{a}$ & $1.44 \mathrm{c}$ & $7.4 \mathrm{a}$ & $7.2 \mathrm{a}$ & $7.4 \mathrm{a}$ & $7.2 \mathrm{a}$ & - & \multicolumn{2}{|c|}{$1.38 \mathrm{c}$} \\
\hline \multicolumn{12}{|l|}{ Mulch } \\
\hline Weed mat & & & & & & & & & $4.1 \mathrm{~b}$ & $1.51 \mathrm{~b}$ & $1.44 \mathrm{bc}$ \\
\hline \multicolumn{12}{|l|}{ Significance $^{\mathrm{y}}$} \\
\hline \multicolumn{12}{|l|}{ Main plot analysis } \\
\hline Bed type (B) & \multicolumn{2}{|c|}{0.6305} & \multicolumn{2}{|c|}{0.1622} & \multicolumn{4}{|c|}{0.1010} & 0.2221 & & \\
\hline Subplot analysis & & & & & & & & & & & \\
\hline Fertilizer $(\mathrm{F})$ & $<0$. & & & 001 & & & 001 & & 0.0847 & & \\
\hline $\mathrm{B} \times \mathrm{F}$ & 0.0 & & & & & & & & 0.3261 & & \\
\hline $\mathrm{B} \times \mathrm{F} \times \mathrm{M}$ & & & & & & & & & 0.2259 & & \\
\hline Cultivar (C) & $<0$. & & & 001 & & & 001 & & 0.9683 & & 01 \\
\hline $\mathrm{B} \times \mathrm{C}$ & & & & & & & & & 0.7205 & & \\
\hline $\mathrm{F} \times \mathrm{C}$ & & & & & & & & & 0.1963 & & \\
\hline $\mathrm{B} \times \mathrm{F} \times \mathrm{C}$ & & & & & & & & & 0.7356 & & \\
\hline $\mathrm{M} \times \mathrm{C}$ & & & & & & & & & 0.3743 & & \\
\hline $\mathrm{B} \times \mathrm{M} \times \mathrm{C}$ & & & & & & & & & 0.1527 & & \\
\hline $\mathrm{F} \times \mathrm{M} \times \mathrm{C}$ & & & & & & & & & 0.0266 & & \\
\hline $\mathrm{B} \times \mathrm{F} \times \mathrm{M} \times \mathrm{C}$ & & & & & & & & & 0.7182 & & \\
\hline Contrasts & & & & & & & & & & & \\
\hline Feather vs. fish & $<0$. & & & 001 & & & 001 & & 0.0291 & & \\
\hline Low $\mathrm{N}$ vs. high $\mathrm{N}$ & $<0$. & 01 & & 001 & & & 001 & & 0.1595 & & \\
\hline Weed mat vs. organic & $<0$. & & & & & & & & $<0.0001$ & & \\
\hline Sawdust vs. compost & 0.1 & & & & & & & & 0.1006 & & \\
\hline
\end{tabular}

${ }^{\mathrm{z}}$ Means followed by the same letter, within treatments, are not significantly different $(P>0.05$, using Tukey's honestly significant difference test).

${ }^{\mathrm{y}}$ Treatments that are significantly different $(P<0.05)$ are bolded for ease of reference.

$\mathrm{K}=$ potassium; $\mathrm{N}=$ nitrogen $\mathrm{P}=$ phosphorus; $\mathrm{Ca}=$ calcium; $\mathrm{Mg}=$ magnesium .

blueberry plants, and plant uptake of K likely affected its uptake of $\mathrm{Ca}$ and $\mathrm{Mg}$ adversely. Application of $\mathrm{K}$ fertilizer to soil low in $\mathrm{K}$ $\left(0.001\right.$ to $\left.0.03 \mathrm{~g} \cdot \mathrm{kg}^{-1}\right)$ increased soil and leaf $\mathrm{K}$ levels and yield of 'Bluecrop' blueberry in Michigan (Eck, 1983) but had no impact on yield of 'Jersey' blueberry grown in the same region in soil with 0.03 to $0.08 \mathrm{~g} \cdot \mathrm{kg}^{-1} \mathrm{~K}$ (Hancock and Nelson, 1988).

Fish emulsion contained more $\mathrm{K}$ than feather meal. Consequently, soil and leaf K were also higher with fish emulsion, whereas leaf $\mathrm{Ca}$ and $\mathrm{Mg}$ levels were lower. Leaf $\mathrm{K}$ was within the range recommended for blueberry ( 4 to $7 \mathrm{~g} \cdot \mathrm{kg}^{-1}$; Hart et al., 2006) the first season but exceeded standards the second year when a high rate of fish emulsion was applied. Because $\mathrm{K}$ was high in the fish emulsion, increasing the rate of $\mathrm{N}$ applied also increased amount of $\mathrm{K}$ applied. Some have also reported an increase in leaf $\mathrm{K}$ with $\mathrm{N}$ rate (Bishop et al., 1971; Cummings, 1978; Cummings et al., 1971; Townsend, 1973; Wilber and Williamson, 2008), although others have found no effect (Bryla et al., 2012). Fluctuations in leaf $\mathrm{K}$ are often associated with fruiting; however, the plants in the present study had no fruit the first year and only a small crop the second year (Larco et al., 2013).

Leaf $\mathrm{Ca}$ was below recommended levels (4.1 to $8.0 \mathrm{~g} \cdot \mathrm{kg}^{-1}$; Hart et al., 2006) for plants fertilized with fish emulsion. Feather meal provided additional $\mathrm{Ca}\left(12 \mathrm{~kg} \cdot \mathrm{ha}^{-1}\right.$ per year at the high rate) but had no effect on leaf $\mathrm{Ca}$. In addition, the high $\mathrm{Ca}$ added in the compost + sawdust mulch had no effect on leaf $\mathrm{Ca}$ in the second year. Low soil Ca under weed mat led to low leaf Ca levels in 'Liberty', which was more vigorous than 'Duke' (Larco et al., 2013). Leaf $\mathrm{Ca}$ did not increase from Year 1 to Year 2, as reported previously by others (Bryla et al., 2012; Cummings, 1978; Townsend, 1973).

Leaf $\mathrm{Mg}$ was below recommended levels for blueberry (1.3 to $2.5 \mathrm{~g} \cdot \mathrm{kg}^{-1}$; Hart et al., 2006) in all treatments in Year 1 except 'Duke' fertilized with feather meal. Although compost contained a relatively high amount of $\mathrm{Mg}$, the nutrient was apparently unavailable to the plants during the first 2 years after the compost was applied. Leaf $\mathrm{Mg}$ also declined with a higher rate of fertilizer, likely because soil $\mathrm{K}$ also increased. Leaf $\mathrm{Mg}$ was unaffected by $\mathrm{N}$ rate in other studies in conventional blueberry (Ballinger and Kushman, 1966; Bishop et al., 1971; Bryla et al., 2012; Cummings et al., 1971). We found an increase in leaf $\mathrm{Mg}$ over time, as reported previously by others (Bryla et al., 2012; Cummings, 1978; Townsend, 1973).

In general, leaf $\mathrm{K}, \mathrm{Ca}$, and $\mathrm{Mg}$ were higher in 'Duke' than in 'Liberty' during the first year after planting, particularly when plants were fertilized with fish emulsion (for leaf $\mathrm{K}$ ) or feather meal (for leaf $\mathrm{Ca}$ and $\mathrm{Mg}$ ). Leaf $\mathrm{K}$ and $\mathrm{Mg}$ were also higher in 'Duke' in Year 2, but leaf $\mathrm{Ca}$ was similar between the two cultivars.

Leaf and soil micronutrients. Leaf B was below recommended levels in plants fertilized with fish emulsion in the first year and in all treatments the next year. Boron in the feather meal fertilizer was apparently available quickly to the plants the first season but was inadequate for $B$ needs in the plants the next year. Boron deficiency is common in areas with high rainfall, especially in alluvial soils, which are common in Oregon. Possible symptoms of B deficiency, shoot tip dieback, were observed in some plots but were minimal and could not be attributed to any specific treatment. Soil and leaf B were higher with compost + sawdust than with sawdust alone but were similar between sawdust and weed mat. The latter observation was similar in cherry (Choi et al., 2011). Leaf B declined the second year likely because plants were fruiting and B levels are relatively high in fruit tissue.

Leaf Mn concentrations mirrored soil $\mathrm{pH}$, as expected, decreasing with addition of compost + sawdust mulch and increasing with fish emulsion and the higher rate of $\mathrm{N}$ fertilizer (Bañados et al., 2012; Choi et al., 2011; Hart et al., 2006; Townsend, 1973). We 
found an increase in leaf Mn over time, as reported previously by others (Bryla et al., 2012; Cummings, 1978; Townsend, 1973).

There were no consistent effects of mulch treatment or fertilizer on leaf $\mathrm{Cu}$ and $\mathrm{Zn}$ after 2 years, although the plots mulched with compost + sawdust increased soil $\mathrm{Cu}$ and $\mathrm{Zn}$ relative to mulching with sawdust alone. In cherry, mulch had no impact on leaf Fe, $\mathrm{Cu}$, or B after 6 years (Choi et al., 2011).

In general, leaf $\mathrm{B}$ and $\mathrm{Mn}$ levels were higher in 'Duke' than in 'Liberty' the first year, whereas leaf $\mathrm{Cu}$ was lower. The oppo- site was true the next year, however, and leaf Zn was lower in 'Duke'.

\section{Conclusions}

Application of organic fertilizer affected macro- and micronutrients in soil and the leaves during the first 2 years after planting in blueberry, but results varied depending on fertilizer source and associated nutrient content. For example, 12 times more $\mathrm{Ca}$ and seven times more B were applied with feather meal than with fish emulsion, which increased

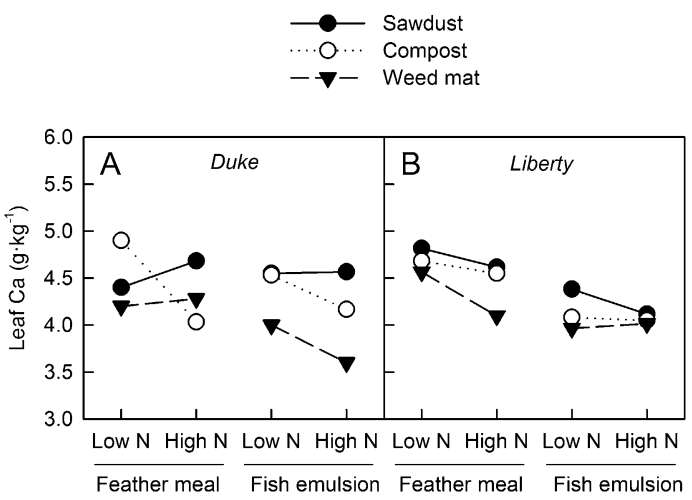

Fig. 4. Interaction effects of organic fertilizer and mulch on leaf calcium $(\mathrm{Ca})$ concentration in 'Duke' (A) and 'Liberty' (B) blueberry during the second year after planting, Aug. 2008.

soil $\mathrm{Ca}$ and $\mathrm{B}$; however, feather meal only increased leaf $\mathrm{B}$ and had no effect on leaf $\mathrm{Ca}$, suggesting that the extra $\mathrm{Ca}$ in the fertilizer was unavailable to the plants. Potassium, on the other hand, was 100-fold higher in fish emulsion and resulted in higher levels of soil and leaf $\mathrm{K}$ than feather meal but decreased leaf $\mathrm{Ca}$ and $\mathrm{Mg}$. Phosphorus and $\mathrm{Cu}$ were also higher in fish emulsion and resulted in increased soil $\mathrm{P}$ and $\mathrm{Cu}$ and leaf $\mathrm{P}$.

Application of fish emulsion at a high rate also led to a reduction in soil $\mathrm{pH}$. Fish emulsion appeared to be an acceptable fertilizer source for blueberry during establishment and may be useful for increasing acidity in high $\mathrm{pH}$ soils. However, high rates of application were found to reduce growth and yield in 'Duke' (Larco et al., 2013). Feather meal is also well suited to blueberry, particularly when soil B is limited (like it was at our site), but the fertilizer must be applied early. If feather meal is used, we recommend the first application be done in late winter when rainfall is adequate to dissolve the fertilizer and ensure that $\mathrm{N}$ is available to the plant in the spring when needed.

Yard debris compost covered with a layer of sawdust mulch (to reduce weeds) increased soil $\mathrm{pH}$, organic matter, $\mathrm{NO}_{3}-\mathrm{N}, \mathrm{P}$, $\mathrm{K}, \mathrm{Ca}, \mathrm{B}, \mathrm{Cu}$, and $\mathrm{Zn}$ relative to sawdust alone but had no effect on leaf $\mathrm{N}, \mathrm{P}$, or $\mathrm{Ca}$ concentrations. Because plants mulched with

Table 7. Effects of fertilizer and mulch on leaf micronutrients in 'Duke' and 'Liberty' blueberry grown on flat or raised beds during the second year after planting (Aug. 2008).

\begin{tabular}{|c|c|c|c|c|c|c|c|c|c|c|c|c|}
\hline \multirow[b]{3}{*}{ Treatment } & & & & & \multicolumn{4}{|c|}{ Leaf Mn $\left(\mathrm{mg} \cdot \mathrm{kg}^{-1}\right)$} & \multicolumn{4}{|c|}{ Leaf $\mathrm{Zn}\left(\mathrm{mg} \cdot \mathrm{kg}^{-1}\right)$} \\
\hline & \multicolumn{2}{|c|}{ Leaf B $\left(\mathrm{mg} \cdot \mathrm{kg}^{-1}\right)$} & \multicolumn{2}{|c|}{ Leaf Cu $\left(\mathrm{mg} \cdot \mathrm{kg}^{-1}\right)$} & \multicolumn{2}{|c|}{ Bed type } & \multicolumn{2}{|c|}{ Cultivar } & \multicolumn{2}{|c|}{ Bed type } & \multicolumn{2}{|c|}{ Cultivar } \\
\hline & Duke & Liberty & Duke & Liberty & Flat & Raised & Duke & Liberty & Flat & Raised & Duke & Liberty \\
\hline \multicolumn{13}{|l|}{ Fertilizer } \\
\hline Feather meal (low N) & $21 b^{z}$ & $29 \mathrm{a}$ & & & $88 \mathrm{~d}$ & $92 \mathrm{~cd}$ & $77 \mathrm{e}$ & $103 \mathrm{~d}$ & $13.2 \mathrm{~cd}$ & $12.8 \mathrm{~d}$ & $16.1 \mathrm{~b}$ & $9.9 \mathrm{~d}$ \\
\hline Feather meal (high N) & $22 \mathrm{bc}$ & $26 \mathrm{ab}$ & & & $87 \mathrm{~d}$ & $120 \mathrm{a}-\mathrm{c}$ & $87 \mathrm{e}$ & $120 \mathrm{bc}$ & $13.4 \mathrm{~cd}$ & $14.5 \mathrm{ab}$ & $17.6 \mathrm{a}$ & $10.3 \mathrm{~d}$ \\
\hline Fish emulsion (low N) & $18 \mathrm{c}$ & $21 \mathrm{bc}$ & & & $113 \mathrm{~b}-\mathrm{d}$ & $127 \mathrm{a}-\mathrm{c}$ & $111 \mathrm{~cd}$ & $130 \mathrm{~b}$ & $13.9 \mathrm{bc}$ & $13.0 \mathrm{~cd}$ & $16.6 \mathrm{ab}$ & $10.3 \mathrm{~d}$ \\
\hline Fish emulsion (high N) & $19 \mathrm{c}$ & $20 \mathrm{c}$ & & & $176 \mathrm{a}$ & $161 \mathrm{ab}$ & $165 \mathrm{a}$ & $170 \mathrm{a}$ & $14.9 \mathrm{a}$ & $13.3 \mathrm{~cd}$ & $16.4 \mathrm{~b}$ & $11.8 \mathrm{c}$ \\
\hline \multicolumn{13}{|l|}{ Mulch } \\
\hline Sawdust & \multicolumn{2}{|c|}{$21 \mathrm{~b}$} & $2.5 \mathrm{a}$ & $1.7 \mathrm{c}$ & $119 \mathrm{~b}$ & $136 \mathrm{a}$ & \multicolumn{2}{|c|}{-} & \multicolumn{2}{|c|}{ - } & $18.0 \mathrm{a}$ & $11.2 \mathrm{c}$ \\
\hline Compost & \multicolumn{2}{|c|}{$26 \mathrm{a}$} & $2.3 \mathrm{a}$ & $1.3 \mathrm{~d}$ & $106 \mathrm{~b}$ & $119 \mathrm{~b}$ & \multicolumn{2}{|c|}{-} & \multicolumn{2}{|c|}{-} & $17.2 \mathrm{a}$ & $10.4 \mathrm{~cd}$ \\
\hline Weed mat & \multicolumn{2}{|c|}{$20 \mathrm{~b}$} & $2.0 \mathrm{bc}$ & $2.0 \mathrm{bc}$ & $124 \mathrm{ab}$ & $121 \mathrm{~b}$ & \multicolumn{2}{|c|}{ - } & \multicolumn{2}{|c|}{ - } & $14.8 \mathrm{~b}$ & $10.1 \mathrm{~d}$ \\
\hline \multicolumn{13}{|l|}{ Significance } \\
\hline \multicolumn{13}{|l|}{ Main plot analysis } \\
\hline Bed type (B) & \multicolumn{2}{|c|}{0.2168} & \multicolumn{2}{|c|}{0.2782} & \multicolumn{4}{|c|}{0.4829} & & 0.7 & 765 & \\
\hline Subplot analysis & & & & & & & & & & & & \\
\hline Fertilizer (F) & & & & & & $<\mathbf{0 . 0}$ & & & & & 192 & \\
\hline $\mathrm{B} \times \mathrm{F}$ & & & & & & $\mathbf{0 . 0}$ & & & & & 65 & \\
\hline Sub-subplot analysis & & & & & & & & & & & & \\
\hline Mulch (M) & & 001 & & & & 0.0 & & & & $<0$. & 001 & \\
\hline $\mathrm{B} \times \mathrm{M}$ & & & & & & 0.0 & & & & & 30 & \\
\hline $\mathrm{F} \times \mathrm{M}$ & & & & & & 0.23 & & & & & 365 & \\
\hline $\mathrm{B} \times \mathrm{F} \times \mathrm{M}$ & & & & & & $0.2^{-}$ & & & & 0.6 & 12 & \\
\hline Cultivar (C) & & 001 & $<0$ & 001 & & $<\mathbf{0 . 0}$ & & & & $<0$. & 001 & \\
\hline $\mathrm{B} \times \mathrm{C}$ & & & & & & 0.6 & & & & & 65 & \\
\hline $\mathrm{F} \times \mathrm{C}$ & & & & & & 0.0 & & & & & 85 & \\
\hline $\mathrm{B} \times \mathrm{F} \times \mathrm{C}$ & & & & & & 0.3 & & & & & 16 & \\
\hline $\mathrm{M} \times \mathrm{C}$ & & & & & & 0.12 & & & & & 100 & \\
\hline $\mathrm{B} \times \mathrm{M} \times \mathrm{C}$ & & & & & & 0.0 & & & & & 767 & \\
\hline $\mathrm{F} \times \mathrm{M} \times \mathrm{C}$ & & & & & & $0.6 ?$ & & & & & 263 & \\
\hline $\mathrm{B} \times \mathrm{F} \times \mathrm{M} \times \mathrm{C}$ & & & & & & $0.5^{\prime}$ & & & & & 320 & \\
\hline Contrasts & & & & & & & & & & & & \\
\hline Feather vs. fish & & & & & & $<\mathbf{0 . 0}$ & & & & & 219 & \\
\hline Low N vs. high $\mathrm{N}$ & & & & & & $<\mathbf{0 . 0}$ & & & & 0.0 & 103 & \\
\hline Weed mat vs. organic & & 001 & & & & 0.20 & & & & $<0$. & 001 & \\
\hline Sawdust vs. compost & & 001 & & & & 0.0 & & & & & 393 & \\
\hline
\end{tabular}

${ }^{\mathrm{z}}$ Mean separation by Tukey's honestly significant difference test at the 0.05 level.

$\mathrm{Mn}=$ manganese; $\mathrm{Zn}=$ zinc; $\mathrm{B}=$ boron; $\mathrm{Cu}=$ copper; $\mathrm{N}=$ nitrogen. 
compost + sawdust produced a higher yield than sawdust alone (Larco et al., 2013), factors other than $\mathrm{N}$ or $\mathrm{N}$ availability were related to the higher yield. The high soil $\mathrm{P}$ found in this study likely masked any additional $\mathrm{P}$ applied with the compost. Higher $\mathrm{Mg}$ applied with the compost was also not reflected in higher soil $\mathrm{Mg}$ levels. In contrast, $\mathrm{K}$ and $\mathrm{B}$ in the compost were quickly available to the blueberry plants. Like fish emulsion, higher $\mathrm{K}$ in the compost was associated with lower leaf $\mathrm{Ca}$ and $\mathrm{Mg}$; this could have a negative impact on plant growth or fruit production if tissue $\mathrm{Ca}$ and $\mathrm{Mg}$ drop to below sufficiency levels. Thus, the long-term effect of using yard debris compost as a source of organic matter and nutrients in blueberry production systems, particularly the impact on soil and plant $\mathrm{K}$, needs further evaluation. The high $\mathrm{pH}$ compost, on the other hand, may help mitigate increases in soil acidity that often occurs when organic or $\mathrm{NH}_{4}$ sources of $\mathrm{N}$ fertilizer, including fish emulsion and feather meal, are applied.

Soil $\mathrm{pH}$ was lowest under weed mat than under sawdust or compost + sawdust. Weed mat also reduced soil $\mathrm{Ca}$ and $\mathrm{Mg}$, but its impact on leaf nutrient concentrations was more variable. The long-term impacts of weed mat on soil $\mathrm{pH}$, organic matter, and $\mathrm{K}$ need further investigation, particularly because reduced microbial activity and fluxes of $\mathrm{N}$ and $\mathrm{P}$ through the microfauna have been observed under weed mat compared with organic mulches (Forge et al., 2003).

Finally, bed type had no effect on soil conditions, but in many cases, it significantly affected leaf nutrients in one or both cultivars, particular during the first year after planting. Plant growth and early production were also affected by bed type, and both were generally higher on raised beds (Larco et al., 2013), perhaps as a result of greater root growth or activity. Raised beds are recommended for both conventional and organic production of highbush blueberry.

\section{Literature Cited}

Ballinger, W.E. and L.J. Kushman. 1966. Factors affecting the mineral-element content of leaves and fruit of Wolcott blueberries. Proc. Amer. Soc. Hort. Sci. 88:325-330.

Bañados, M.P., B.C. Strik, D.R. Bryla, and T.L. Righetti. 2012. Response of highbush blueberry to nitrogen fertilizer during field establishment. I. Accumulation and allocation of fertilizer nitrogen and biomass. HortScience 47:648-655.

Bishop, R.F., L.R. Townsend, and D.L. Craig. 1971. Effect of source and rate of $\mathrm{N}$ and $\mathrm{Mg}$ on nutrient levels in highbush blueberry leaves and fruit. HortScience 6:37-38.

Bryla, D.R., R.G. Linderman, and W.Q. Yang. 2008. Incidence of Phytophthora and Pythium and the relation to cultural conditions in commercial blueberry fields. HortScience 43:260263.

Bryla, D.R. and R.M.A. Machado. 2011. Comparative effects of nitrogen fertigation and granular fertilizer application on growth and availability of soil nitrogen during establishment of highbush blueberry. Frontiers Plant Sci. 2:1-8.
Bryla, D.R., B.C. Strik, M.P. Bañados, and T.L. Righetti. 2012. Response of highbush blueberry to nitrogen fertilizer during field establishment-II. Plant nutrient requirements in relation to nitrogen fertilizer supply. HortScience 47:917-926.

Burkhard, N., D. Lynch, D. Percival, and M. Sharifi. 2009. Organic mulch impact on vegetation dynamics and productivity of highbush blueberry under organic production. HortScience 44:688-696.

Chandler, R.B. and E.C. Mason. 1942. The effect of mulches on soil moisture, soil temperature, and growth of blueberry plants. Proc. Amer. Soc. Hort. Sci. 40:335-337.

Choi, H.-S., C.R. Rom, and M. Gu. 2011. Plant performance, and seasonal soil and foliar nutrient variations in an organic apple orchard under four ground cover management systems. J. Amer. Pom. Soc. 65:130-146.

Clark, J.R. and J.N. Moore. 1991. Southern highbush blueberry response to mulch. HortTechnology 1:52-54.

Cox, J. 2009. Comparison of plastic weedmat and woodchip mulch on low chill blueberry soil in New South Wales, Australia. Acta Hort. 810: 475-482.

Cummings, G., C. Bickford, and L. Nelson. 1971. Fertilizer and lime rates influence highbush blueberry growth and foliar elemental content during establishment. J. Amer. Soc. Hort. Sci. 96:184-186.

Cummings, G.A. 1978. Plant and soil effects of fertilizer and lime applied to highbush blueberries. J. Amer. Soc. Hort. Sci. 103:302-305.

Dahnke, W.C. 1990. Testing soils for available nitrogen, p. 120-140. In: Westerman, R.L. (ed.). Soil testing and plant analysis. Soil Sci. Soc. Amer. Book Ser. 3, Madison, WI.

Eck, P. 1983. Optimum potassium nutritional level for production of highbush blueberry. J. Amer. Soc. Hort. Sci. 108:520-522.

Eck, P. 1988. Blueberry science. Rutgers Univ. Press, New Brunswick, NJ.

Forge, T.A., E. Hogue, G. Neilsen, and D. Neilsen. 2003. Effects of organic mulches on soil microfauna in the root zone of apple: Implication for nutrient fluxes and functional diversity of the soil food web. Appl. Soil Ecol. 22:39-54.

Gale, E.S., D.M. Sullivan, C.G. Cogger, A.I. Bary, D.D. Hemphill, and E.A. Myhre. 2006. Estimating plant-available nitrogen release from manures, compost and specialty products. J. Environ. Qual. 35:2321-2332.

Gavlak, R.G., D.A. Horneck, and R.O. Miller. 1994. Plant, soil and water reference methods for the western region. Western Region Ext. Pub. 125 (WREP-125). Univ. Alaska, Fairbanks, AK.

Griggs, W.H. and H.A. Rollins. 1947. The effect of planting treatment and soil management systems on the production of cultivated blueberries. Proc. Amer. Soc. Hort. Sci. 49:213-218.

Hancock, J.F. and J. Nelson. 1988. Leaf potassium content and yield in the highbush blueberry. HortScience 23:857-858.

Hanson, E.J. 2006. Nitrogen nutrition of highbush blueberry. Acta Hort. 715:347-351.

Hart, J., B. Strik, L. White, and W. Yang. 2006. Nutrient management for blueberries in Oregon. Ore. State Univ. Ext. Serv. EM 8918.

Hart, J.M., D.M. Sullivan, N.P. Anderson, A.G. Hulting, D.A. Horneck, and N.W. Christensen. 2013. Soil acidity in Oregon: Understanding and using concepts for crop production. Ore. State Univ. Ext. Serv. EM 9061.

Horneck, D.A., D.M. Sullivan, J.S. Owen, and J.M. Hart. 2011. Soil test interpretation guide. Ore. St. Univ. Ext. Serv. EC 1478.
Julian, J., B. Strik, and W. Yang. 2011a. Blueberry economics: The costs of establishing and producing blueberries in the Willamette Valley, Oregon. Ore. St. Univ. Pub. AEB 0022. < http:// arec.oregonstate.edu/oaeb/files/pdf/AEB0022. pdf $>$.

Julian, J., B. Strik, E. Pond, and W. Yang. 2011b. Blueberry economics: The costs of establishing and producing organic blueberries in the Willamette Valley, Oregon. Ore. St. Univ. Pub. AEB 0023. <http://arec.oregonstate.edu/oaeb/ files/pdf/AEB0023.pdf $>$.

Julian, J.W., B.C. Strik, H.O. Larco, D.R. Bryla, and D.M. Sullivan. 2012. Cost of establishing organic northern highbush blueberry: Impacts of planting method, fertilization, and mulch type. HortScience 47:866-873.

Karp, K., M. Noormets, M. Starast, and T. Paal. 2006. The influence of mulching on nutrition and yield of 'Northblue' blueberry. Acta Hort. 715:301-305.

Kozinski, B. 2006. Influence of mulching and nitrogen fertilization rate on growth and yield of highbush blueberry. Acta Hort. 715:231235.

Krewer, G., M. Tertuliano, P. Andersen, O. Liburd, G. Fonsah, H. Serri, and B. Mullinix. 2009. Effect of mulches on the establishment of organically grown blueberries in Georgia. Acta Hort. 810:483-488.

Larco, H., B.C. Strik, D.R. Bryla, and D.M. Sullivan. 2013. Mulch and fertilizer management practices for organic production of highbush blueberry. I: Plant growth and allocation of biomass during establishment. HortScience 48:1250-1261.

Larco, H.O. 2010. Effect of planting method, weed management, and fertilizer on plant growth and yield of newly established organic highbush blueberries. MS thesis, Ore. St. Univ., Corvallis, OR.

McLean, E.O. 1982. Soil $\mathrm{pH}$ and lime requirement, p. 199-223. In: Page, A.L., R.H. Miller, and D.R. Keeney (eds.). Methods of soil analysis. Part 2. Chemical and biological properties. 2nd Ed. Agron. Monogr. 9. Soil Sci. Soc. Amer., Madison, WI.

Mehlich, A. 1984. Mehlich-3 soil test extractant: A modification of Mehlich-2 extractant. Commun. Soil Sci. Plant Anal. 15:14091416.

Neilsen, G.H., E.J. Hogue, T. Forge, and D. Neilsen. 2003. Surface application of mulches and biosolids affect orchard soil properties after 7 years. Can. J. Soil Sci. 83:131-137.

Nelson, D.W. and L.E. Sommers. 1996. Total carbon, organic carbon and organic matter, $\mathrm{p}$. 961-1010. In: Sparks, D.L. (ed.). Methods of soil analysis. Part 3. Chemical methods. 3rd Ed. Book Ser. 5. Soil Sci. Soc. Amer., Madison, WI.

Retamales, J.B. and E.J. Hanson. 1989. Fate of ${ }^{15} \mathrm{~N}$-labeled urea applied to mature highbush blueberries. J. Amer. Soc. Hort. Sci. 114:920 923.

Sabey, B.R., W.V. Bartholomew, R. Shaw, and J. Pesek. 1956. Influence of temperature on nitrification in soils. Soil Sci. Soc. Amer. J. 20:357360.

Savage, E.F. 1942. Growth responses of blueberries under clean cultivation and various kinds of mulch materials. Proc. Amer. Soc. Hort. Sci. 40:335-337.

Scherm, H. and G. Krewer. 2008. Disease management in organic rabbiteye blueberries. Intl. J. Fruit Sci. 8:1-2.

Sciarappa, W., S. Polavarapu, J. Barry, P. Oudemans, M. Ehlenfeldt, G. Pavlis, D. Polk, and R. Holdcraft. 
2008. Developing an organic production system for highbush blueberry. HortScience 43: 51-57.

Sikora, L.J. and R.A.K. Szmidt. 2001. Nitrogen sources, mineralization rates, and nitrogen nutrition benefits to plants from composts, $\mathrm{p}$. 287-305. In: Stofella, P.J. and B.A. Kahn (eds.). Compost utilization in horticultural cropping systems. CRC Press, Boca Raton, FL.

Strik, B. 2007. Horticultural practices of growing highbush blueberries in the ever-expanding U.S. and global scene.. J Amer. Pomol. Soc. 61:148-150.

Thompson, W.H., P. Leege, P. Millner, M. Watson (eds.). 2001. Test methods for the examination of composting and compost (TMECC). U.S. Composting Council, Ronkonkoma, NY.

Throop, P.A. and E.J. Hanson. 1997. Effect of application date on absorption of ${ }^{15}$ nitrogen by highbush blueberry. J. Amer. Soc. Hort. Sci. 122:422-426.

Townsend, L.R. 1973. Effects of N, P, K, and Mg on the growth and productivity of the highbush blueberry. Can. J. Plant Sci. 53:161168.

Wedryk, S., J. Felix, D. Doohan, and J. Cardina. 2012. Strategies for weed suppression and improving soil fertility during transition to organic vegetable production. Hort Technology 22:207-214.
White, L.D. 2006. The effect of pre-plant incorporation with sawdust, sawdust mulch, and nitrogen fertilizer rate on soil properties and nitrogen uptake and growth of 'Elliott' highbush blueberry. MS thesis, Ore. St. Univ., Corvallis, OR.

Wilber, W.L. and J.G. Williamson. 2008. Effects of fertilizer rate on growth and fruiting of containerized southern highbush blueberry. HortScience 43:143-145.

Yin, X., C.F. Seavert, J. Turner, R. Núñez-Elisea, and H. Cahn. 2007. Effects of polypropylene groundcover on soil nutrient availability, sweet cherry nutrition, and cash cost and returns. HortScience 42:147-151. 